UNIVERSIDADE DE SÃO PAULO

FACULDADE DE FILOSOFIA, LETRAS E CIÊNCIAS HUMANAS

DEPARTAMENTO DE LETRAS MODERNAS

PROGRAMA DE PÓS-GRADUAÇÃO EM LÍNGUA FRANCESA

\title{
A FUNÇÃO DO LÚDICO NO ENSINO/APRENDIZAGEM DE LÍNGUA ESTRANGEIRA: UMA VISÃO PSICOPEDAGÓGICA DO DESEJO DE APRENDER
}

Sergio Luiz Baptista da Silva

Dissertação apresentada ao Programa de Pós-Graduação em Língua e Literatura Francesa do Departamento de Letras Modernas da Faculdade de Filosofia, Letras e Ciências Humanas da Universidade de São Paulo para a obtenção do título de Mestre.

Orientadora: Profa. Dra. Maria Sabina Kundman 


\section{Banca Examinadora}

1)

2)

3) 



\section{Agradecimentos}

À minha mãe, Alayde, que sem as fatias de amor e dedicação não teria chegado aonde cheguei.

Aos meus tios e tias, primos e primas que participaram da minha formação.

À Profa. Dra. Maria Sabina Kundman, pela orientação e apoio dado em tantos momentos difíceis.

Aos meus amigos por me ajudarem nessa jornada.

Aos colegas da Puc, pelo incentivo dado, em especial a Denise por ter caminhado mais próximo nos momentos de dificuldades.

Aos alunos da $7^{a}$. série $P$ do Liceu Pasteur, pois sem eles não teria realizado este trabalho.

E, finalmente , ao Jotassê, por ter, durante todo o processo, oferecido a escuta positiva, o carinho e a dedicação. 


\section{Resumo}

Esta pesquisa busca investigar qual o papel das técnicas lúdicas no ensino de Língua Estrangeira, verificando, sobretudo, as reações dos alunos frente a esta abordagem lúdica.

Este trabalho procura ainda entender o que leva o aluno a querer aprender uma Língua estrangeira. Questiona o papel do professor frente ao conteúdo a ser ensinado e, se ele, enquanto ensinante, pode fazer algo concretamente para que o aluno deseje aprender a LE.

Todos os questionamentos são colocados a partir da Psicopedagogia, em especial dos aportes de Alicia Fernandez, lembrando que sua obra tem um forte vínculo com a psicanálise, em especial com a obra de Winnicott, tão instigante no que se refere ao lúdico.

A experiência prática, aqui descrita, deu-se em uma escola privada na cidade de São Paulo, com um grupo da $7^{a}$. série do ensino fundamental. Para a sua realização, utilizou-se a Técnica de Simulação Global de Francis Yaiche. Todo o percurso foi traçado a partir das experiências e inquietações do pesquisador, que é professor de língua francesa há 20 anos.

Palavras-chave: Lúdico - Psicopedagogia - Desejo - Metodologia do Ensino de Línguas Estrangeiras - Simulação Global. 


\begin{abstract}
This research aims at investigating the role of ludic technics in the Foreign Language Teaching, verifyng, mainly, the students's reactions in this ludic aproach.
\end{abstract}

This work also intents to understand what makes a student want to learn a foreign language and what stimulates them. It also intends to discuss the teacher's role before the instuctions of contents and if the teacher could do something concrete to make his student desire to learn a foreign language.

All the questions based on Psychopegadogy, in special, the Alicia Fernández's works which have a strong attachement to psychanalysis, mainly to Winnicott's thoughts, which are so instiganting to the ludic analysis.

This experience was carried out in a private school in São Paulo, with a "7a . série group" from "foundamental level”. The Global Simulation Technics from Francis Yaiche were the tools used to investigate the ludic functions in the Foreign Language Teaching. The whole process was drawn from the researcher's twenty year's experience in the classroom.

Key-words: Ludic - Psychopedagogy - Desire - Foreign language Methodology - Global Simulation. 


\section{Résumé}

Cette recherche a eu pour but vérifier le rôle de techniques ludiques dans l'enseignement de Langues Étrangères, à partir surtout de l'analyse des réactions des élèves face à cette approche ludique.

On a eu aussi l'intention de comprendre ce qui mène un élève à avoir le désir d'aprendre une Langue Étrangère, ainsi que de vérifier ce qu'on peut faire pour le stimuler. On discute le rôle du professeur face aux contenus à enseigner et si, en tant qu'enseignant, il peut faire concrètement quelque chose pour créer chez l' élève le désir d' apprendre la LE.

Toutes les questions sont posées à partir de la Psychopédagogie, en spécial des aports d'Alicia Fernández. Sans oublier que son oeuvre a une relation très forte avec la psychanalyse, surtout avec l'oeuvre de Winnicott, si inquiétante en ce qui concerne le ludique.

L'expérience a été réalisée dans une école privée de São Paulo, auprès d'un groupe d 'éléves de " 7 . série" de "I 'enseignement fondamental". On s'est servi de la technique de la Simulation Globale de Francis Yaiche pour analyser la fonction du ludique dans l'enseignement des Langues Étrangères.

Mots-clé: Ludique - Psychopédagogie - Désir - Méthodologie de l'Enseignement des Langues Étrangères - Simulation Globale. Pédagogiques. 
O saber é como essa Árvore do Paraíso. Dentro de cada um, tenta, impulsiona, convoca, busca a certeza da verdade absoluta e impossível. No entanto, ao comer do seu fruto, podemos perder a felicidade incorpórea do Éden. Sem dúvida, atrever-se a esse jogo sempre nos permitirá saborear algo do saber-sabor do impossível.

Alicia Fernández 
SUMÁRIO

INTRODUÇÃO

1. ALGUMAS CONCEPÇÕES DO LÚDICO ( JOGAR E BRINCAR)

1.1. Huizinga

1.2. Caillois

1.3. Winnicott

1.4. Alicia Fernández

2. O JOGO E O DESEJO DE APRENDER.

2.1. O Desejo segundo a Psicanálise

2.2. A Estrutura do Desejo e a Estrutura Cognitiva

2.3. A Aquisição do Conhecimento, o Saber e o Jogo

2.4. $O$ Jogo e o Ensino/Aprendizagem de Língua Estrangeira

3. A ABORDAGEM COMUNICATIVA E O LÚDICO

3.1. O Lúdico e a Abordagem Comunicativa

3.2. Os Jogos de Papéis (“Jeux de Roles” - JdR)

3.3. A Simulação Global

4. A EXPERIÊNCIA LÚDICA COM OS ALUNOS DE $7^{\text {A }}$. SÉRIE

4.1. Uma Breve História da Instituição

4.2. O Perfil da Classe e dos Alunos do Liceu

4.2.1. A Classe objeto da pesquisa

4.3. 0 "Método Café Creme"

4.4. Relatos das Atividades de Pesquisa realizadas em 2001 
4.5. Comentários sobre o Percurso Percorrido.nas atividades de Simulação Global

4.5.1. Criação da cidade de Boubolet

4.5.2. Diálogos praticados visando à aplicação de atos de fala aprendidos

4.5.3. Convites para a exposição final

4.5.4. Jornal da cidade

4.5.5. Atividades referentes às unidades $1,2,3$, e 4 do método Café Crème 2

4.5.6. Apreciação pelos alunos das atividades realizadas de Simulação Global

4.5.7. Condução dos trabalhos

4.6. O Lúdico e a Prática Pedagógica.

5. CONCLUSÃO

6. BIBLIOGRAFIA

7. ANEXOS 


\section{Introdução}

Trabalho como professor de Línguas há mais de vinte anos. Comecei minha carreira como professor de Português e dois anos depois passei a dar aulas de francês e de inglês. A partir de 1989 dediquei-me unicamente ao Francês. Vieram a seguir os estágios pedagógicos na França, estágios que reforçaram ainda mais meu espírito francófilo. Procurei sempre aperfeiçoar meus conhecimentos não só do ponto de vista lingüístico, mas também pedagógico. Trabalhei em vários tipos de estabelecimento (escola pública, privada, empresa, etc.), com alunos de faixa etária variada e nível sócioeconômico diferenciado. Pude sempre notar nos alunos um grande interesse por um certo tipo de aula na qual as atividades eram diversificadas e a interação entre professor e aluno mais freqüente. Percebi que, quando o envolvimento na aula é maior e o clima é agradável e prazeroso, o aluno se apropria mais facilmente dos conhecimentos transmitidos, tornando-se sujeito de suas produções. Parece-me importante ressaltar, no ensino-aprendizagem da língua estrangeira a importância da criação do espaço transicional, na formulação de Winnicott, espaço de amizade, cordialidade e confiança que facilita a comunicação entre professor e alunos, incentivando os aprendentes a se tornarem autores de suas produções. Acredito que as atividades lúdicas, pelas características descritas no decorrer do trabalho, criam na sala de aula uma atmosfera que propicia a interação e a aprendizagem dos alunos.

Os Jogos de Simulação Global utilizados na experiência realizada com alunos da $7^{a}$ série do Liceu Pasteur permitiram-me verificar que o envolvimento criado facilitou a memorização e a fixação dos conhecimentos lingüísticos transmitidos. Tenho plena consciência de que o percurso da aprendizagem nem sempre é fácil. Nós, professores, não podemos perder de vista a tensão inerente ao "jogo". Toda atividade que se diz "lúdica" apresenta problemas, desafios, espaços a ser conquistados, conhecimentos a ser adquiridos. Em suma, jogar não é fácil. Mas jogar é entrar na atmosfera do ilusório, do mundo 
do Faz-de-Conta, mundo que incentiva a criação de sensações, emoções, sentimentos que aumentam o desejo de aprender. Para jogar, é preciso acreditar no jogo, sentir-se ligado a ele, daí o sentido religioso lembrado por Huizinga (1996) ${ }^{1}$. O jogo na sala de aula possui o mesmo aspecto carismático e religioso que tem na sociedade: estabelece elos profundos entre as pessoas envolvidas no ato sagrado, no ato comunicativo - no caso específico, na interação na sala de aula.

Aprender uma língua estrangeira em um meio institucional traz sempre à tona a questão da autenticidade na sala de aula. Creio que a autenticidade está justamente na convicção, na crença de que aquilo que se está produzindo (conhecimento e saber na outra língua) é parte integrante dos sujeitos envolvidos na tarefa que está sendo executada. O "faz-de-conta" facilita a criação do mundo dos desejos e da ilusão. Se, por ventura, algum aluno, não se envolver na tarefa, por alguma razão cognitiva ou psicológica, ele ficará automaticamente fora do jogo, não fará parte dele e poderá até comprometer o seu andamento, tornando-se um Desmancha-Prazer (Huizinga - 1996). Mas, se se envolver, acabará aderindo ao jogo, ao grupo, à construção desse mundo ilusório, que para ele pode se tornar real.

Não é aconselhável reduzir essa questão da não adesão a um mero descaso do aluno em relação ao que lhe é oferecido. Não é improvável que outros fatores relevantes estejam envolvidos nessa não-adesão por parte de alguns alunos.

Podemos nos perguntar, professores e alunos, sobre qual a função do lúdico nas aulas de língua estrangeira. É minha intenção, nesse trabalho, mostrar a concepção e as características do jogo, e a importância do brincar e do jogar na formação do indivíduo. O emprego do jogo na sala de aula cria não

\footnotetext{
1 "De tudo isso decorre claramente, pelo menos para mim, uma conseqüência: que é impossível perder de vista, por um momento que seja, o conceito de jogo, em tudo que diz respeito à vida religiosa dos povos primitivos. Somos forçados constantemente, para descrever numerosos fenômenos, a empregar a palavra "jogo". Mais ainda: a unidade e a invisibilidade da crença e da incredulidade, a indissolúvel ligação entre a gravidade do sagrado e o " faz de
} 
só uma atmosfera de descontração favorável à aprendizagem, mas também incentiva os alunos a participar, a querer se comunicar, a ser criativos. Convém acrescentar que a pesquisa realizada não teve preocupações de ordem quantitativa. Preocupou-se, sobretudo em observar, analisar e avaliar cada momento do processo de aprendizagem vivenciado por meio de jogos.

No primeiro capítulo da dissertação, são apresentadas concepções e características do jogo levantadas por autores que marcaram o meu percurso, tais como Huizinga e Caillois, Winnicott e Alicia Fernández. Um de meus objetivos é mostrar a importância do lúdico no ensino-aprendizagem da língua estrangeira.

Gostaria de ressaltar a importância do papel do professor nesse percurso. É importante que o professor consiga criar na sala de aula o espaço transicional descrito por Winnicot, no qual a interação se realiza. O conhecimento só se torna saber quando é desejado. Pretendo dizer com isso que aprender uma língua estrangeira é sobretudo questão de desejo. Durante muito tempo, o ensino de línguas estrangeiras teve suas técnicas de aprendizagem baseadas em correntes e áreas do conhecimento que levavam em conta sobretudo os processos conscientes de aquisição. As técnicas então aplicadas não levavam em consideração os processos inconscientes. Ora, muitas interrogações surgiram sobre essas práticas. Uma questão sempre presente em minhas reflexões é a seguinte: o que podemos nós, professores de língua estrangeira, fazer para incentivar nossos alunos? A essa questão a maioria dos professores procura dar respostas de ordem racional, deixando de lado aspectos da afetividade e do inconsciente, o que é de lamentar.

A aprendizagem, questão ligada ao desejo, é um fenômeno no qual a reciprocidade é fundamental. É preciso que haja alguém que queira ensinar e alguém que queira aprender.

conta" e o divertimento, são melhor compreendidas no interior do próprio conceito de jogo". Huizinga (p.28)". 
O espaço entre, o espaço transicional do qual fala Winnicott (1975) é um espaço de jogo, de brincadeira, mas também de confiança. É importante fazer com que o desejo de aprender já existente nesse espaço se mantenha e se fortifique. Aliás, a prática pedagógica nos demonstra que somente quando se consegue construir esse espaço é que se mantém no aluno o interesse e o desejo de aprender e de prosseguir.

No capítulo $2^{\circ}$ procuro mostrar como a estrutura desejante atua na estrutura cognitiva para a aquisição dos conhecimentos e a diferença entre o conhecer e o saber.

No capítulo 3 falo da importância do lúdico na abordagem comunicativa e tento caracterizar as dramatizações, os jogos de papel e as simulações globais, técnicas usadas na experiência descrita no capítulo 4.

No capítulo 4 relato a experiência vivenciada no ano de 2001, numa das salas da sétima série de um colégio da rede privada de São Paulo: o Liceu Franco-Brasileiro. Procuro descrever as Simulações Globais propostas e as reações obtidas. Além disso, faço um pequeno histórico do estabelecimento onde se realizou a experiência e traço rapidamente o perfil de sua clientela.

O objetivo da experiência realizada foi o de mostrar a importância da introdução de atividades lúdicas no ensino/aprendizagem das línguas estrangeiras e a validade das hipóteses presentes, entre elas, a de que o emprego dos jogos criaria um ambiente de descontração favorável à aprendizagem e à assimilação e fixação dos conhecimentos. 


\section{Primeiro Capítulo: Algumas Concepções do Lúdico (Jogar e brincar)}

\subsection{Definições sobre o jogo e a brincadeira}

Apresentaremos neste capítulo algumas concepções e características do lúdico, relacionadas ao jogar e ao brincar. Para isso, faremos uma breve apresentação das idéias de alguns autores que marcaram nosso percurso e nortearam nossa pesquisa.

\section{HUIZINGA}

Lúdico vem do latim inludere, inlusio, que significa ilusão.

Segundo Huizinga (1996), todos nós, humanos, temos intrinsecamente a capacidade, assim como também a necessidade, de jogar.

Para Huizinga o "jogo é uma função da vida, mas não é passível de definição exata em termos lógicos, biológicos ou estéticos”. (p.10). Em razão da dificuldade de bem definir o que seja jogo, Huizinga procura apresentar suas características fundamentais.

Para o autor,

[...] o conceito de jogo deve permanecer distinto de todas as outras formas de pensamento através das quais exprimimos a estrutura da vida espiritual e social. Teremos, portanto de limitar-nos a descrever suas principais características. (p.10). 
Huizinga afirma que o "jogo é uma atividade voluntária. [...] Sujeito a ordens, deixa de ser jogo, podendo no máximo ser uma atividade forçada."(p.10). O jogo "só se torna uma necessidade urgente na medida em que o prazer por ele provocado o transfoma numa necessidade." (p.11).

A primeira das características fundamentais apontadas por Huizinga 'é o fato de o jogo "ser livre, de ser ele próprio liberdade".(p. 11).

Uma segunda característica levantada pelo autor e intimamente ligada à primeira é que "o jogo não é vida 'corrente', 'nem vida real'." (p.11).

Na realidade, o jogo propicia uma evasão da vida "real", uma imersão no "mundo do faz-de-conta". Não se conclua daí, entretanto, um caráter de não "seriedade do jogo" (p.11). Segundo Huizinga,

[...] esta consciência do fato de 'só fazer de conta' não impede de modo algum que o jogo se processe com a maior seriedade, com um enlevo e um entusiasmo que chegam ao arrebatamento. (p. 11).

O fascínio do jogo é de tal ordem que ele "é capaz, a qualquer momento de absorver inteiramente o jogador." (pg 11).

Outra característica do jogo é que ele é "desinteressado", ou seja, "ele se situa fora do mecanismo de satisfação imediata das necessidades e dos desejos." (p. 11).

O jogo se caracteriza ainda por ser uma atividade temporária, "que se realiza tendo em vista uma satisfação que consiste 'em sua própria realização'“. (p. 12). 
A terceira das características principais do jogo consiste no "isolamento", "na limitação". O jogo se realiza num espaço e num tempo limitado. Convém, entretanto, acrescentar que, embora o espaço e o tempo utilizado sejam limitados, eles são extremamente significativos, uma vez que deixam freqüentemente marcas profundas na memória (p.13). Pode parecer estranho, mas "o jogo cria ordem e é ordem". Há nele também uma tendência de ser belo (p. 13).

"Apesar de seu ardente desejo de ganhar", todo jogador "deve obedecer às regras do jogo" (p. 14). O jogador que desrespeita ou ignora as regras do jogo é considerado um "desmancha-prazeres". Esse jogador acaba privando os participantes, com sua atitude, do caráter ilusório do jogo.

Huizinga aponta ainda para o caráter "livre" dessa atividade, "conscientemente tomada como 'não-séria" (p.16). Na realidade, para o autor, as duas características fundamentais encontradas no jogo são "uma luta por alguma coisa ou a representação de alguma coisa" (p. 16).

Uma outra característica importante do jogo levantada por Huizinga é a "de se fixar como fenômeno cultural" e a de estar presente já nas sociedades primitivas.

Para finalizar, gostaríamos de ressaltar no jogo, não só o seu aspecto lúdico, mas também o seu caráter sagrado e religioso.

Huizinga lembra:

[...] a unidade e a indivisibilidade da crença e da incredulidade, a indissolúvel ligação entre a gravidade do sagrado e o 'faz de conta' do divertimento, são características melhor compreendidas no interior do próprio conceito do jogo. (p. 28). 
Huizinga ressalta a presença, no jogo, das seguintes características lúdicas: ordem, tensão, movimento, mudança, solenidade, ritmo, entusiasmo (p. 30).

$\mathrm{Na}$ realidade, a noção de jogo associa-se, para o autor, a duas vertentes fundamentais: a do lúdico e a do sagrado, com inúmeras outras implicações, o que acaba levando o jogador a uma sensação de divertimento, euforia e prazer, mas também de arrebatamento e de enlevo.

Para finalizar, e retomando o próprio Huizinga:

A intensidade do jogo e seu poder de fascinação não podem ser explicados por análises biológicas. E, contudo, é nessa intensidade, nessa fascinação, nessa capacidade de excitar que reside a própria essência e a característica primordial do jogo. (p.5).

\section{Caillois}

Caillois (1958) assim se expressa sobre a obra de Huizinga:

Son ouvrage n'est pas une étude des jeux, mais une recherche sur la fécondité de l'esprit de jeu dans le domaine de la culture, et plus précisément de l'esprit qui préside à une certaine espèce de jeux: les jeux de compétition réglée. L'examen des formules de départ dont se sert Huizinga pour circonscrire le champ de ses analyses aide à comprendre d'étranges lacunes d'une enquête d'ailleurs en tout point remarquable. (p. 32). 
Caillois faz as seguintes considerações sobre os jogos:

sobre a liberdade de participação do jogador:

Un jeu auquel on se trouverait forcé de participer cesserait aussitôt d'être un jeu: il deviendrait une contrainte, une corvée dont on aurait hâte d'être délivré. ( p.36).

On ne joue que si l'on veut, que quand on veut, que le temps qu'on veut, en ce sens, le jeu est une activité libre. (p. 38).

\section{sobre a limitação no espaço e no tempo:}

En effet, le jeu est essentiellement une occupation séparée, soigneusement isolée du reste de l'existence, et accomplie en général dans des limites précises de temps et de lieu. (p. 37).

\section{sobre o caráter imprevisível da atividade :}

[...] le jeu est une activité libre. II est en outre une activité incertaine. Le doute doit demeurer jusqu'à la fin sur le dénouement. (p. 38).

Un déroulement connu d'avance, sans possibilité d'erreur ou de surprise, conduisant clairement à un résultat inéluctable, est incompatible avec la nature du jeu. (p. 39) .

\section{sobre a liberdade da resposta nos limites da regra :}

Le jeu consiste dans la nécéssité de trouver, d' inventer immédiatement une réponse qui est libre dans les limites des règles. (p. 39).

\section{sobre o caráter regrado ou fictício dos jogos:}

[...] les jeux ne sont pas réglés et fictifs. Ils sont plutôt ou réglés ou fictifs".(p. 41). 
O autor tenta ressaltar a dificuldade de bem definir e caracterizar 0 jogo, em razão de sua variedade e diversidade.

Para Caillois (1958), o jogo é elemento de fundamental importância na afirmação de si mesmo e na formação do caráter:

On le voit: le panorama de la fécondité culturelle des jeux ne laisse pas d'être impréssionant. Leur contribution au niveau de l'individu n'est pas moindre. Les psychologues leur reconnaissent un rôle capital dans I'histoire de l'affirmation de soi chez l'enfant et dans la formation de son caractère. (p.18).

Assim, Caillois caracteriza os jogos como sendo uma atividade:

Livre: na qual o jogador não é obrigado a jogar, sem o que o jogo perde seu caráter de diversão, atração e prazer. (p. 43).

Separada: na medida em que está circunscrita a limites de espaço e de tempo precisos, fixados antecipadamente. (p. 43).

Incerta: o resultado não é fixado previamente, em virtude da liberdade de criação do jogador. (p. 43).

Improdutiva: o jogador se encontra, no fim, em posição idêntica à do começo, porque a atividade não cria bens nem riquezas, ou coisa semelhante. (p. 43).

Regrada: submetida momentaneamente a certas convenções. (p. 43).

Fictícia: acompanhada de um sentimento de franca irrealidade em relação à vida corrente. (p. 43). 
Caillois propõe a seguinte classificação para os jogos: Agôn, Alea, Mimicry e llinx, em razão da predominância das seguintes funções: competição (Agôn), azar (Alea), simulacro (Mimicry) ou vertigem (llinx) (p. 47)

Conviria acrescentar que no interior dessas funções há gradações, apelidadas por Caillois de Paidia e ludus. Paidia é sobretudo marcada pela sensação de diversão, pela predominância do sentimento de turbulência e improvisação, e ludus pelo controle desse sentimento de exuberância de elementos de natureza anárquica e caprichosa e pela observância de regras:

A une extrémité règne, presque sans partage, un principe commun de divertissement, de turbulence, d'improvisation libre et d'épanouissement insouciant, par où se manifeste une certaine fantaisie incontrôlée qu'on peut désigner sous le nom, de paidia. À l'extrémité opposée, cette exubérance espiègle et primesautière est presque entièrement absorbée, en tout cas disciplinée, par une tendance complémentaire inverse à quelques égards, mais non à tous de sa nature anarchique et capricieuse....Je nomme ludus cette seconde composante. (p. 48).

Tipologia dos jogos segundo Caillois :

Agôn: jogos de competição: tais como corridas, esgrima, xadrez, etc. Tout un groupe de jeux apparaît comme compétition, c'est à dire comme un combat où l'égalité des chances est artificiellement créée pour que les antagonistes s'affrontent dans des conditions idéales, susceptibles de donner une valeur précise et incontestable au triomphe du vainqueur. (p. 50).

La différence avec l'agôn est que, dans le ludus, la tension et le talent du joueur s'exercent en dehors de tout sentiment explicite d'émulation 
ou de rivalité: on lutte contre l'obstacle et non contre un ou plusieurs concurrents. (p. 80).

Alea; jogos de azar tais como: cara ou coroa, loterias, roleta, etc.

C'est en latin le nom du jeu de dés. Je l'emprunte ici pour désigner tous jeux fondés, à l'exact opposé de l'agôn, sur une décision qui ne dépend pas du joueur, sur laquelle il ne saurait avoir la moindre prise, et où il s'agit par conséquent de gagner bien moins sur un adversaire que sur le destin. ( p. 56).

L'agôn et l'alea traduisent des attitudes opposées et en quelque sorte symétriques, mais ils obéissent tous deux à une même loi :la création artificielle entre les joueurs des conditions d'égalité pure que la réalité refuse aux hommes. (p. 60).

Mimicry: jogos de simulação: máscara, imitações, teatro, artes de espetáculo, etc.

Tout jeu suppose l'acceptation temporaire, sinon d'une illusion (encore que ce dernier mot ne signifie pas autre chose qu'entrée en jeu; inlusio), du moins d'un univers clos, conventionnel et à certains égards, fictif. Le jeu peut consister . non pas à déployer une activité ou à subir un destin dans un milieu imaginaire, mais à devenir soi-même un personnage illusoire et à se conduire en conséquence. (p.60/61).

Mimique et travesti sont ainsi les ressorts complémentaires de cette classe de jeux. (p. 61).

O autor diz que esse tipo de jogo está presente na criança e no adulto. Caillois acrescenta que a representação teatral e a interpretação dramática são os exemplos mais significativos dessa tendência. 
O autor afirma ainda com relação a essa vertente: "Le plaisir est d'être autre ou de se faire passer pour un autre”. (p. 64)

Para Caillois, a atividade, a imaginação, a interpretação estão presentes na mimicry. Para o autor, a mimicry não tem ligações com a alea mas pode se compor com a agôn (p. 65).

Caillois diz ainda da mimicry:

La mimicry est invention incessante. La règle du jeu est unique: elle consiste pour le spectateur à se présenter à l'illusion sans recuser de prime abord le décor, le masque, l'artifice auquel on l'invite à ajouter foi, pour un temps donné, comme à un réel plus réel que le réel. ( $p$. $67)$.

Ilinx: jogos de vertigem tais como: carrossel, balanço, ski, alpinismo, etc.

Une dernière espèce de jeux rassemble ceux qui reposent sur la poursuite du vertige et qui consistent en une tentative de détruire pour un instant la stabilité de la perception et d'infliger à la conscience lucide une sorte de panique voluptueuse. (p. 67).

Convém acrescentar que nos jogos há freqüentemente mescla de atividades, embora quase sempre haja predominância de algumas delas. Nas aulas de LE preponderam as três primeiras atividades, embora atualmente haja predomínio da tendência mimicry, ou seja, das dramatizações, dos jogos de papel, dos jogos teatrais e das simulações .

Resumindo, vamos relembrar as considerações que Caillois faz sobre os jogos: 
Sous l'angle de la forme, on peut donc, em bref définir le jeu comme une action libre, sentie comme fictive et située en dehors de la vie courante, capable néanmoins d'absorber totalement le joueur; une action dénuée de tout intérêt matériel et de toute utilité; qui s'accomplit en un temps et dans un espace expressément circonscrits, se déroule avec ordre selon des règles données et suscite dans la vie des relations de groupe s'entourant volontiers de mystère ou accentuant par le déguisement leur étrangeté vis-à-vis du monde habituel. (1958, p.32/33).

Para finalizar, ressaltamos a importância atribuída por Caillois aos jogos na própria formação do indivíduo:

On le voit: le panorama de la fécondité culturelle des jeux ne laisse pas d'être impréssionant. Leur contribution au niveau de l'individu n'est pas moindre. Les psychologues leur reconnaissent un rôle capital dans I'histoire de l'affirmation de soi chez l'enfant et dans la formation de son caractère. (p.18).

\section{Winnicott}

O psiquiatra inglês Winnicott é seguramente na área psicanalítica, o estudioso que mais se interessou por questões relativas ao lúdico na formação do indivíduo.

O espaço transicional por ele criado - espaço da brincadeira - é fruto de reflexões decorrentes de suas análises clínicas, sobretudo de crianças, mas também de adolescentes e adultos. 
O espaço transicional é, segundo Winnicott (1975), o espaço da ilusão $^{2}$. E é nesse espaço entre, que não é nem dentro nem fora, que se estabelece a brincadeira. As crianças brincam mais facilmente, sem as barreiras psíquicas da vida adulta. Mas, segundo o autor, os adultos não só podem, como também devem brincar e jogar, entrar no mundo do "faz-deconta", no mundo da ilusão.

O espaço lúdico, o espaço transicional onde se brinca é, segundo o autor a garantia da boa saúde mental:

A Psicoterapia se efetua na sobreposição de duas áreas do brincar, a do paciente e a do terapeuta. A psicoterapia trata de duas pessoas que brincam juntas. Em conseqüência, onde o brincar não é possível, o trabalho efetuado pelo terapeuta é dirigido então no sentido de trazer o paciente de um estado em que não é capaz de brincar para um estado em que o é. (p.59).

Em outras palavras, o brincar é, segundo o autor e a psicanálise, um ato, um agir sobre o objeto, uma ação que garante a sanidade mental:

Winnicott (1975) afirma:

[...] é a brincadeira que é universal e que é própria da saúde: o brincar facilita o crescimento e, portanto, a saúde; o brincar conduz aos relacionamentos grupais [...] (p.63).

Winnicott acrescenta ainda:

O brincar é inerentemente excitante e precário. Essa característica não provém do despertar institual, mas da precariedade própria ao interjogo na mente da criança do que é subjetivo (quase-alucinação) e do que é objetivamente percebido (realidade concreta ou realidade compartilhada). (p. 77).

\footnotetext{
${ }^{2}$ Interessante que inludere se refere à ilusão, ao iludir. O termo lúdico surgiu da palavra latina inlusio.
} 
O autor afirma: "É no brincar, talvez apenas no brincar, que a criança ou o adulto fruem sua liberdade de criação". (p.79)

Winnicott acrescenta ainda que é no brincar que se dá a constituição do sujeito:

É no brincar, e somente no brincar, que o indivíduo, criança ou adulto, pode ser criativo e utilizar sua personalidade integral: e é somente sendo criativo que o indivíduo descobre o eu (self). Ligado a isso, temos o fato de que somente no brincar é possível a comunicação. (p. 80)

O brincar é, pois, para o autor, de extrema importância: "É com base no brincar, que se constrói a totalidade da existência experiencial do homem". (p. 93).

Com relação ao espaço potencial Winnicott assim se pronuncia:

De um estado de sentir-se fundido à mãe, o bebê passa para um estádio de separá-la do eu(self), enquanto a mãe diminui o grau de sua adaptação às necessidades do bebê(tanto em consequência de se ter recuperado de um alto grau de identificação com ele, quanto devido à sua percepção da nova necessidade dele, a necessidade de que ela seja um fenômeno separado. (p.14).

Winnicott (1975) explicita o conceito de fenômeno e objeto transicional: Introduzi os termos 'objetos transicionais' e 'fenômenos transicionais' para designar a área intermediária entre o polegar e o ursinho, entre o erotismo oral e a verdadeira relação de objeto, entre a atividade criativa primária e a projeção do que já foi introjetado. (p.14). 
Reivindico aqui um estado intermediário entre a inabilidade de um bebê e uma crescente habilidade em reconhecer e aceitar a realidade. Estou, portanto estudando a substância da ilusão, aquilo que é permitido ao bebê e que, na vida adulta, é inerente à arte e à religião. (p.15).

Os objetos transicionais e os fenômenos transicionais pertencem ao domínio da ilusão que está na base do início da experiência. Esse primeiro estádio do desenvolvimento é tornado possível pela capacidade especial, por parte da mãe, de efetuar adaptações às necessidades de seu bebê, permitindo-lhe assim a ilusão de que aquilo que ele cria existe realmente. (p. 30).

Não é o objeto, naturalmente, que é transicional. Ele representa a transição do bebê de um estado em que este está fundido com a mãe para um estado em que está em relação com ela como algo externo e separado. (p.30).

Se pensarmos em termos pedagógicos, poderemos dizer que é nesse "espaço entre", entre o de dentro e o de fora, entre o subjetivo e o objetivo, onde a ilusão está instaurada, que o professor deve criar situações e tarefas onde o brincar e o jogar estejam presentes, o que facilita a introdução do aprendente num outro universo, o da aprendizagem da língua estrangeira. E é nesse espaço de confiança, de mundo "faz-de-conta", de ilusão, de interação, que o aluno pode sentir prazer em brincar, em se comunicar em língua estrangeira.

Na história das metodologias do Ensino da LE percebe-se, sobretudo a partir do enfoque comunicativo, uma tendência de introdução do jogo na sala de aula, pelo seu aspecto interacionista, estimulante e provocador, capaz de levar o aluno à construção do conhecimento. Entretanto, nota-se também que um grande contingente de professores se esquivam desse tipo de atividade por julgá-la não adequada em razão de fugir do programa tradicional estabelecido 
pela escola e/ou órgãos competentes. Trata-se, na realidade, de um grande equívoco, uma vez que o lúdico propicia um desbloqueio que favorece a aprendizagem.

\section{Alicia Fernández}

Segundo Alicia Fernández:

Tradicionalmente, de acordo com uma visão racionalista e dualista do ser humano, considerou-se a aprendizagem exclusivamente como um processo consciente e produto da inteligência, deixando o corpo e os afetos fora; mas se houve humanos que aprenderam é porque não fizeram caso de tal teoria e "fugiram dos métodos educativos sistematizados. (1991, p. 47).

Para a autora, na aprendizagem entram sempre em jogo:

- o "organismo individual herdado";

- o "corpo construído especularmente";

- a "inteligência autoconstruída interacionalmente";

- a "arquitetura do desejo", o desejo que é sempre desejo do desejo de Outro".

Em "Estructuras inconscientes del pensamiento e "La Génesis del Inconsciente" Sara Paín define a aprendizagem "como o processo que permite a transmissão do conhecimento de um outro que sabe (um outro do conhecimento) a um sujeito que vai chegar a ser sujeito, exatamente através da aprendizagem". (in Fernández 1991, p. 51).

- $\quad$ Alicia declara que, na realidade, o que se transmite ao aprendente não é o conhecimento, mas sinais desse conhecimento para que o sujeito possa não só transformá-lo, mas também reproduzi-lo. (1991, p. 52).

A autora afirma ainda que o ser humano pode transformar o que ela chama de "enseña" em conhecimento, que se caracteriza por passar por 
quatro níveis de elaboração: orgânico, corporal, intelectual e semiótico ou desejante, níveis que funcionam sempre num processo dialético com o exterior. (1991, p. 52).

A autora considera que é importante relacionar em estudos sobre a aprendizagem questões ligadas à inteligência e aos desejos inconscientes, habitualmente estudadas isoladamente (1991 p.70). Isto porque na aprendizagem, segundo ela, "intervêm o nível cognitivo e o desejante, além do organismo e do corpo". (1991, p. 74).

"O problema de aprendizagem põe em evidência a necessária interrelação dos níveis orgânico, corporal, intelectual e desejante, a partir de sua articulação sintomática" (1991, p.129). A teotria psicopedagógica procura dar conta da articulação inteligência-desejo.

Alicia Fernández (1991) faz uma distinção entre conhecimento e saber:

O conhecimento é objetivável, transmissível de forma indireta ou impessoal; pode ser adquirido através de livros ou máquinas; é factível de ser sistematizado em teorias; enuncia-se através de conceitos. Por outro lado, o saber é transmissível só diretamente, de pessoa a pessoa, experiencialmente; não se pode aprender através de um livro, nem de máquinas, não é sistematizável (não existem tratados de saber); pode ser enunciado somente através de metáforas, paradigmas, situações, casos clínicos [...] O saber dá poder de uso. Os conhecimentos não. (1991, p.129).

Uma grande falha de nossa educação tem a ver com a desqualificação do saber e o endeusamento do conhecimento. Pode-se entender porque convém a determinados sistemas que circulem os conhecimentos, mas não o poder de uso sobre eles. (1991, p.129). 
Com relação ao espaço para aprender, ao espaço para jogar, Alicia Fernández se pronuncia da seguinte forma :

O saber se constrói fazendo próprio o conhecimento do outro, e a operação de fazer próprio o conhecimento do outro só se pode fazer jogando. Aí encontramos uma das intersecções entre o aprender e o jogar.

O conhecimento o possui o Outro, e só pode ser adquirido de maneira indireta; ao contrário, o saber, que é uma construção pessoal e outorga possibilidade de uso, está relacionado com o fazer, com o encarnar o conhecimento de acordo com os caracteres pessoais.

Não pode haver construção de saber, se não se joga com o conhecimento. Ao falar de jogo, não estou fazendo referência a um ato, nem a um produto, mas a um processo. Estou me referindo a esse lugar e tempo que Winnicott chama de espaço transicional, de confiança, de criatividade. Transicional entre o crer e o não crer, entre o dentro e o fora. (p.165).

Sobre o ensinante e o aprendente Alicia Fernández se expressa da seguinte forma:

Sabemos que para aprender é necessário um ensinante e um aprendente que entrem em relação. Isto é algo indiscutível quando se fala de métodos de ensino e de processos de aprendizagem normal; não obstante, costuma-se esquecê-lo quando se trata de fracasso de aprendizagem. Aqui pareceria, então, que só entra em jogo o aprendente que fracassa. Como se não se pudesse falar de ensinantes ou de vínculos que fracassam ou produzem sintomas. Por ensinantes entendo tanto o docente ou a instituição educativa, como o pai, a mãe, o amigo ou quem seja investido pelo aprendente e/ou pela cultura, para ensinar. ( $A$ Inteligência Aprisionada, p.32)

Para a autora, o espaço da sala de aula deve ser um espaço de confiança, um espaço entre, o mesmo espaço lúdico de Winicott, no qual o conhecimento se transforma em saber. Alicia afirma que todo saber é original, 
particular de cada sujeito. Só sabemos aquilo que for passível de transformação, de conhecimento interiorizado.

Alicia Fernández preconiza a criação de espaços de confiança entre o ensinante e o aprendente para que o conhecimento venha a se tornar um saber construído pelo sujeito em questão. À produção feita pelo sujeito aprendente a psicopedagoga chama de autoria $^{2}$, o que faz com que o sujeito aprendente se torne autor. Para ela, a autoria de pensamento abre caminho para a autonomia propriamente dita, que vai favorecer a autoria de pensar $(O$ Saber em jogo, p.91).

O pensamento não é autônomo; ao contrário, é por suas ligações com o desejo (e daí com o outro) e por tal relação com os limites do real que é necessário e urgente ao sujeito situar-se como o autor de seu pensar. Sendo assim, poderá ir deixando de ser objeto do desejo do outro para ser sujeito do seu próprio desejo, ou, melhor ainda, para reconhecer-se como sujeito desejante (O Saber em Jogo, p. 90).

Para Alicia Fernández (2001):

Fazer pensável nossa prática é um propósito comum de toda construção teórica; todavia, além disso, coincide com o próprio objeto de intervenção psicopedagógica, pois a psicopedagogia tem como propósito abrir espaços objetivos e subjetivos de autoria de pensamento; fazer pensável as situações, o que não é fácil, já que o pensamento não é somente produção cognitiva, mas um entrelaçamento inteligência-desejo, dramatizado, representado, mostrado e produzido em um corpo. (O Saber em Jogo, p.55).

A visão psicopedagógica trabalhada na experiência realizada com uma das classes da sétima série possibilitou acompanhar e analisar, na sala de aula, a função do lúdico nos jogos de Simulação Global. 
Alicia Fernández afirma:

O lugar 'entre' é também entre a certeza e a dúvida. Se tivéssemos somente certezas, ficaríamos imóveis no passado. Se tivéssemos somente dúvidas, não poderíamos alimentar uma base de sustentação para continuar trabalhando na construção teórica. Aí está a importância da pergunta (O Saber em Jogo, p.55).

As perguntas do aluno e do professor devem estar sempre presentes na dinâmica do processo de ensino-aprendizagem das diferentes disciplinas.

Os elementos apresentados no relato das idéias dos diferentes autores transcritos tentaram caracterizar suas concepções sobre jogos e/ou saber e/ou conhecimento e/ou ensino/aprendizagem, assim como a importância da presença do sentimento de descontração e prazer na aula de língua estrangeira. Possibilitar a aprendizagem da língua através de atividades lúdicas significa, no meu entender, facilitar a entrada do adolescente no mundo do outro, no mundo das diferenças, não só de ordem lingüístico-discursiva, mas também cultural, fazendo com que ele se interesse pelo que é diferente, pelos contrastes existentes, ajudando-o a tornar-se um sujeito desejante e ao mesmo tempo participante da aula de língua estrangeira. 


\section{Capítulo 2 - 0 Jogo e o Desejo de Aprender}

\subsection{O Desejo Segundo a Psicanálise}

A questão do desejo, para a psicanálise, está ligada ao princípio do prazer, presente na primeira experiência humana, ou seja, na primeira mamada do bebê. Trata-se, a princípio, de uma necessidade orgânica, ou seja, o organismo solicita o alimento e este é dado em forma de leite materno ao bebê. $E$, ao saciar a fome, o bebê experimenta, paralelamente, enquanto sujeito, a sua primeira sensação de prazer. O prazer é produzido no exato momento da primeira mamada e o sujeito passa a querer a repetição desse primeiro prazer. E nesse momento o desejo se instaura. O desejo é a falta. Desejando a repetição do sentimento de satisfação experimentado, o sujeito acaba se inserindo num mundo humano em oposição ao mundo animal que é um mundo orientado pelos instintos. Dessa forma, concluímos que o desejo está marcado pelo Outro, pelo que está fora. O objeto não é desejado por si, mas sim pelo significado que o outro atribui a ele.

Lajonquière afirma (1993, p157):

A trama é infinita e onipresente na medida em que o desejo não é (depois de Hegel) desejo de nenhum objeto natural suscetível de ser achado com maior ou menor sorte; o desejo deseja o desejo do outro enquanto outro desejante. Em outras palavras, o objeto do desejo é o desejo do outro, que é mais ou menos o mesmo que dizer que cada um de nós deseja ser desejado pelo outro, exatamente como supomos que o fomos naquela mítica oportunidade.

A mãe deseja que seu filho aceite seu seio, que significa carinho, atenção, proteção e amor. Assim, por analogia, o professor de LE deseja que 
seus alunos desejem aprender a LE em questão, considerada pelo mestre como bela e/ou importante no mundo atual e/ou de grande significação cultural. O objeto, no caso da LE, não é a língua em si, mas os significados que a acompanham e que são atribuídos a ela pelo outro. Em outras palavras, queremos afirmar que o desejo não se confunde com o instinto. Desejar está na ordem do humano. O instinto é de ordem animal, nele não há ação responsabilizada. Tudo está programado no mundo animal, enquanto no mundo humano a ação é selecionada e desejada. Há um sujeito que a realiza em função do desejo do outro.

Garcia-Roza (1994, p.142) afirma:

Mas se o desejo é um vazio, uma falta, e se o EU decorrente de sua satisfação é determinado pelo objeto, o Desejo somente será humano quando se dirigir para um objeto não-natural, caso contrário ele permanecerá sendo um Desejo natural e o Eu continuará também sendo natural, isto é, animal... Desejar o desejo do outro eis o que caracteriza o Eu como Eu humano.

O Desejo humano pode, a despeito do que foi dito, desejar um objeto, mas com a condição de esse objeto estar mediatizado pelo Desejo do outro. Assim, o soldado que arrisca sua vida para arrebatar a bandeira do inimigo não está desejando o pedaço de pano colorido, mas o objeto do desejo de outros.

O desejo nunca encontra sua realização porque ele sempre se remete à primeira satisfação: a do seio materno. Todas as investidas do desejo se voltam para a falta, para a primeira experiência de prazer.

Garcia-Roza diz (1994, p148):

O que aprendemos com Freud foi que o objeto do desejo é um objeto perdido, uma falta, e que esse objeto perdido continua presente como falta, procurando realizar-se através de uma série 
de substitutos que formam uma rede contingente mantendo a permanência da falta.

\subsection{A Estrutura do Desejo e a Estrutura Cognitiva}

Sara Paín (1996) afirma que o grande dilema da pedagogia foi o de ter olvidado na construção do conhecimento as questões subjetivas, as questões da ordem do desejo segundo a psicanálise Ora, segundo ela, a trajetória da constituição do sujeito se faz através do desejo da mãe que por sua vez se torna o desejo do bebê: "O sujeito não é sujeito até que conheça. É sujeito porque conhece, e é sujeito a esse conhecimento".(p.15)

Paín explica que o bebê, ao sugar, ao tomar o seio da mãe, aciona esquemas de ordem cognitiva, que o levam ao prazer, não somente de saciar a fome, mas também de receber carinho, calor e afeto materno. Na realidade, o desejo do bebê se instaura na falta, na falta da mãe, de sua atenção, de sua presença física. É a representação dessa falta que chamamos de desejo.

Paín (1996) esclarece: "O desejo é uma representação que vem ocupar o lugar da falta. Não é a falta, mas a representação que Ihe ocupa o lugar" (p.71).

Nós, humanos, buscamos aquilo que está no outro, no seu desejo, para assim, então, descobrirmos o nosso desejo. Isso se dá com o conhecimento do que é externo, compartilhado. Deseja-se aprender uma LE porque isso está sendo desejado pelo outro, quer pelo professor, quer pelo pai, pelo chefe da empresa, pela mídia, enfim, pelo Outro. Para Paín (1996), o que se encontra fora do sujeito é a realidade constituída por leis que o sujeito não pode anular, ou seja, pela objetividade . O subjetivo é irregular, ou seja, algo singular, em suma, o desejo. O mundo da cultura é dado ao sujeito como algo pronto, já estabelecido, no qual o seu desejo deve se inserir. "A realidade no 
sentido natural não existe para o homem. Tudo que o rodeia está culturalizado, isto é, é portador de conhecimento humano". ( Paín, 1996, p.22).

Paín (1996, p.21) esclarece:

Para que haja desejo, tem de haver falta. Assim, o desejo se instaura em uma irrealidade. A realidade não é somente a realidade deste momento, mas também a realidade do que é possível. Portanto, o pensamento é o pensamento do que eu projeto como possível, dentro da realidade. $\mathrm{Na}$ ordem do desejo, ao contrário, o que se pensa é o impossível.

Há uma via cognitiva da inteligência, da construção do saber. Entretanto, ela não pode ser acionada sem que uma outra via a conduza nesse caminho: a via do desejo. É isso que nos torna humanos e não animais. A inteligência não é algo pronto, dado, sem alterações. Não somos apenas organismos movidos por instintos, como muitos pensam.

\subsection{A Aquisição do Conhecimento, o Saber e o Jogo}

O papel do professor na construção do conhecimento é o de ser o suporte, o de dar crédito à possível produção de seu aluno, o de abrir espaços para a autoria de seu aluno, o de abrir espaço entre, entre ele, professor, e o aluno ou aprendente. Conviria lembrar que, para Alicia Fernández (2001), o espaço entre é o mesmo espaço Transicional lembrado por Winnicott:

A primeira experiência de autoria é o brincar. Algo que se faz porque sim. Algo que se faz sem a demanda do outro e sem a exigência da necessidade. Surge dessa zona intermediária, transicional, que não é nem interior, nem exterior e, por sua vez, a cria.(p.127/128). 
O brincar e o jogo são o desafio necessário para a construção do conhecimento. Segundo Alicia Fernández (2001), o brincar é o que dá significado e delimita os territórios do sujeito aprendente, ou melhor, a sua "individuação". Cada um joga a seu modo: "Os jogos com regras não seriam jogos se não incluíssem obstáculos, e a possibilidade de atravessá-los é o que constrói o jogo" (p.129).

Daí o caráter de seriedade do jogo apontado por Huizinga. Quando o professor de LE joga na sala de aula, propõe um desafio que é parte integrante do jogo em si e que, por felicidade, aponta para resultados imprevisíveis nas produções de cada aluno. O professor cria o espaço para a realização do jogo, mas não detém o poder de forjar resultados. Cada produção, cada autoria, depende da subjetividade de cada aluno. O professor e o aluno se encontram no espaço da brincadeira, no espaço entre, no espaço transicional. E tanto para o aluno quanto para o professor, os jogos são objetos transicionais, sujeitos aos fenômenos transicionais: as autorias de cada aprendente estão marcadas pela subjetividade de cada um. $O$ aluno deseja o desejo de seu professor para poder imprimir no jogo a sua autoria, a marca de sua subjetividade. No dizer de Alicia Fernández (2001):

Mais do que ensinar (mostrar) conteúdos de conhecimentos, ser ensinante significa abrir um espaço para aprender. Espaço objetivo-subjetivo em que se realizam dois trabalhos simultâneos:

a. construção de conhecimentos;

b. construção de si mesmo, como sujeito criativo e pensante. (p.30). 


\subsection{O jogo e o Ensino/Aprendizagem da Língua Estrangeira}

Para Krashen, há uma diferença nos processos de aquisição e aprendizagem de uma LE. Retomando os conceitos de Krashen, Germain explicita (1993, p347) que:

Acquisisition est synonyme $d$ 'apprentissage implicite, informel ou naturel. Apprentissage est synonyme d 'explicite, de formel, et de reflexif ( ou attribué à l 'enseignement). L' apprentissage est un processus grâce auquel les apprenants sont conscients des faits de langue, attentifs, et capables d'en parler. Ils jugent de la grammaticalité des enoncés.

Para Alicia Fernández (1991, p. 59): "Somente ao integrar-se ao saber, o conhecimento é aprendido e pode ser utilizado."

Segundo a autora adquirir está para o saber, que é o fazer inconsciente, assim como o aprender está para o conhecer.Os jogos de simulação, objeto da pesquisa que será apresentada no capítulo 4 , estimulam os dois aspectos presentes no ensino-aprendizagem da língua estrangeira: o da aquisiçao e o da aprendizagem. Em uma atividade de Simulação Global, por exemplo, como a criação de um fôlder (un dépliant) de uma cidade imaginária, os alunos são obrigados a pensar conscientemente no que deve ser dito e na maneira de formular esses enunciados. O conhecimento das características do fôlder já está adquirido, mas na sua realização entrarão inúmeros outros elementos, não só de ordem lingüístico-discursiva, mas também de ordem cultural. Esse é o caráter mágico do jogo, que ao mesmo tempo possui regras, envolve seus participantes e os deixa livres para agir. Podemos todos conhecer as regras de um determinado jogo, mas cada um inventa a sua jogada. Esse é o saber e o encanto do jogo. Cada um faz uso da regra a seu modo. $E$ isso ocorre também com as atividades lúdicas na sala de aula.

O aluno, quando convidado a jogar na aula de língua estrangeira, brinca ou não, joga ou não, de acordo com o seu desejo. Se assimilar o desejo 
do professor, jogará. O professor não controla totalmente a atividade, mas tenta orientá-la, facilitar a comunicação para que o jogo possa ocorrer, mas não o impõe, pois, como ressalva Caillois, caso o fizesse, anularia a fonte principal do jogo: o prazer do jogo e de suas descobertas. 


\section{Capítulo 3 - A Abordagem Comunicativa e o Lúdico}

\section{1 - O Lúdico e a Abordagem Comunicativa}

Para compreender o papel do lúdico na abordagem comunicativa é necessário, inicialmente, tentar entender as linhas diretrizes dessa abordagem que se opôs aos métodos audio-orais e áudio-visuais e que buscou "ensinar uma competência comunicativa, apreender o discurso em sua dimensão global, privilegiar o sentido “. (BÉRARD, 1991, p. 31).

Os adeptos do enfoque comunicativo pensam que:

il ne suffit pas de connaître les règles d'une L2 pour pouvoir communiquer dans cette langue. La connaissance des règles de vocabulaire et des structures grammaticales est une condition nécessaire mais non suffisante pour la communication. Pour communiquer efficacement en L2 il faut, en plus, connaître les règles d'emploi de cette langue. Cela signifie savoir quelles formes linguistiques employer dans telle ou telle situation, avec telle ou telle personne, compte tenu de l'intention de communication ( persuader, donner des ordres, faire une demande, etc)." (GERMAIN, p.203)

A Abordagem Comunicativa tentou mostrar as limitações das tarefas e exercícios até então praticados, embasados na pedagogia do estímulo e resposta da psicologia comportamentalista. Na abordagem comunicativa a língua é concebida como um processo criativo submetido a mecanismos internos. As palavras-chave para os adeptos da competência comunicativa não serão mais estrutura, código, sistema, mas competência comunicativa, discurso, atos de fala, enunciação (in KUNDMAN 1994, p. 42).

O quadro político do início dos anos 70 na Europa marca também um redirecionamento dos rumos da Didática da Língua Estrangeira (DLE), em 
conseqüência da criação do Mercado Comum Europeu, da importância a ser dada à questão da comunicação entre os povos e ao incentivo ao ensino das línguas estrangeiras. Surgem, então, publicações importantes, entre as quais o Système d'Apprentissage des Langues Vivantes par les adultes (1973) e o Niveau-Seuil, adaptado da obra inglesa Thereshol Level, por Coste, D. et alii,1976.

Segundo Martinez (1998):

Un Niveau-seuil, par exemple, constitue "un ensemble d'énoncés en français permettant de réaliser tel acte de parole dans telle situation donné", "a partir duquel chacun (pourra) opérer ses choix en fonction de ses propres objectifs, des contraintes et du contexte spécifique". (Adaption d'un Niveau-Seuil pour des contextes scolaires, 1979, cf. Martinez, p.71).

Com a introdução da Abordagem Comunicativa reformulam-se as concepções de como ensinar e de como aprender. O professor, de acordo com esse enfoque não exerce mais o papel centralizador até então exercido e passa a ser um facilitador de atividades a ser cumpridas. O professor não se apóia mais, sobretudo, nos documentos do manual, como nos enfoques anteriores, mas utiliza o documento autêntico, ou seja, o documento que é elaborado com finalidades não apenas didáticas. Assim, são utilizados, entre outros, artigos de jornal, cardápios de restaurante, boletins de meteorologia, panfletos diversos, etc. O ensino de LE procura trazer para a sala de aula mostras reais de comunicação na vida quotidiana.

Esses documentos ditos autênticos têm sido bastante utilizados nas últimas décadas, mas os professores e os autores de manuais didáticos se interrogam sempre sobre o que seja ser autêntico e sobre como conseguir uma comunicação real, espontânea e autêntica na sala de aula, uma vez que como diz Germain (1993b, p.75): 
on arrive rarement à réproduire les conditions de l 'environement de la vie réelle, de sorte que l'apprenant a peu d'occasions d 'être placé dans de véritables conditions d'échanges langagiers.

Para Jakobovits (apud GERMAIN, 1993B, p.75) a autenticidade na sala de aula é

"[...]. toute interaction orale véritablement produite en classe à des fins de communication et non tout simplement comme prétexte à l' apprentissage de langue ( for real par opposition à pretend).

As atividades pedagógicas na abordagem comunicativa visam a uma real comunicação, levando em conta a intenção de comunicação (GERMAIN, 1993):

Une des caractérisques de l'approche comunicative est que toute activité implique une intention de communication. Les activités privilégiées ne sont plus les "exercices struturaux' chers à la méthode audio-orale, ou les exercices de simple répétition, mais bien les jeux de rôle, les simulations, les résolutions de problèmes, etc. ( p. 211).

Segundo Martinez (1998), nessa nova abordagem a noção de ensino/aprendizagem muda, as tarefas do professor e do aluno são definidas em bases diferentes das anteriores: "I'apprenant est mis en situation d'être I 'acteur autonome de son apprentissage [...]" (p.76).

E o professor:

Il définit, organise et fait accepter, grâce à ses interventions, les tâches et le mode de fonctionnement. II instaure un climat de travail et reste à l'écoute du groupe-classe,des groupes lors des activités autonomes, et des apprenants qui ont leurs styles et leurs parcours d'apprentissage propres. (p. 77). 
Martinez (1998) conclui que, na abordagem comunicativa, dispositivos diversos são utilizados para implicar o aluno em uma comunicação orientada. A linguagem é concebida como um modo de agir sobre o real, de onde surgem certas noções e funções de acordo com pesquisas realizadas na época.

Martinez lembra Jupp (1978):

Dans cette vision dite 'pragmatique' de la langue, les emplois d'un mot trouvent des fonctions différentes dans les différents emplois que lui fera prendre l'intention de l'enonciateur. 'Acte de Parole désignera, à la suite de ces travaux, l'unité minimale de la conversation: un évènément de communication est en effet complexe, constitué de transactions, d'échanges, de séquences, $d^{\prime}$ actes enfin. (p.72).

Para ilustrar basta observar uma situação específica de comunicação: num restaurante, o interlocutor se depara com atos de falas diferentes, tais como: pedir, solicitar, propor, aceitar, recusar, dar opinião.

É necessário lembrar o uso do termo "abordagem" para o enfoque comunicativo, em razão da heterogeneidade teórica que o caracteriza. Puren (1988, p386) esclarece:

Le terme de 'méthodologie' apparaissant aujourd'hui comme trop monolithique et exclusif, on lui préfére celui 'd'approches' (lesquels correspondent à des méthodologies diversifiées en fonction d'éléments externes aux apprenants: différents objectifs, contenus, types de supports...) et de 'démarches' (méthodologies diversifiés en fonction des appprenants euxmêmes: leurs habitudes d'apprentissage, leur psychologie, leur vécu...). (p. 386). 


\subsection{Os Jogos de Papéis (“Jeux de Rôles” - JdR)}

O Jeu de rôles é uma técnica de simulação entre outras. É uma técnica de inspiração teatral que nos permite qualificá-la de expressão dramática (cf. CARÉ,J.M., 1983). Não se trata de uma técnica que visa unicamente ao verbal, segundo Bernard Dufeu (1983). O JdR faz também um apelo ao indivíduo em sua totalidade: corpo, sensibilidade, intelecto. Trata-se do verbal associado a outros recursos significativos, tais como o gestual, o mímico, o espacial, o rítmico.

O JdR vai além das dramatizações propostas pelo método estruturalglobal Sgav. No caso da dramatização, cabia ao aluno introduzir a teatralização: o aluno lia ou decorava o texto com uma certa carga dramática. A dramatização foi, sem dúvida nenhuma, o ponto de partida da técnica dos Jeux de Rôle (JdR) na historia didática do ensino de Língua Estrangeira. O JdR surgiu das denominações dos autores de língua inglesa 'role playing, simulation' mas não se reveste de nenhum caráter psicodrámático ( cf. J.M. Caré, 1983)

Segundo Debyser (1974) dá-se o nome de dramatização a toda interpretação que não se distancie muito do texto original. $\mathrm{Na}$ dramatização, o aluno se presta a interpretar o personagem solicitado pelo professor. Com relação à simulação, Debyser (1976, p25) se exprime da seguinte forma:

La simulation obéit à un canevas relativement précis et réglé à l'avance, même si les participants doivent y faire preuve d'initiative et si la ou les solutions apportées au problème dépendent d'eux.

Debyser (1976) nos mostra que no JdR a animação é feita pelos estudantes envolvidos no jogo. Os personagens são mais espontâneos, mais fantasistas e até mesmo mais caricaturais do que nas dramatizações. Nos 
JdRs não há cenário nem tampouco roteiro a seguir, o texto é do aluno. $O$ professor passa a ser um animador da atividade, um diretor discreto da cena, segundo Bernard Dufeu (1983).

Jean-Marc Caré ( 1983, p.38) completa:

Technique du 'comme si', du joué, de l'imité, le jeu de rôle devrait pouvoir se distinguer de la simulation.

Alors qu'en simulation on développe une situation dont les composantes essentielles doivent être programéés á l'avance (scénario) et sont donc prévisibles, le jeu de rôles est avant tout le lieu de I ímprovisation, donc de l'imprévisible.

Mesmo que exista um roteiro para o $\mathrm{JdR}$, o roteiro da situação proposta pelo professor é aberto ( "canevas ouvert"). Imaginemos que se solicite ao grupo uma determinada situação, ou seja, que os integrantes do grupo estejam em uma comemoração de final de ano em um restaurante, por exemplo. Como o "canevas é aberto", os diferentes integrantes do grupo acharão um desfecho diferente para a situação vivida. Nos métodos áudiovisuais Sgav, o roteiro era fechado, o aluno devia memorizar o texto, decorá-lo. (cf. Caré, 1989, p.51)

O que marcou a passagem da abordagem estruturalista para a abordagem comunicativa (cf. CARÉ, 1989, p. 50) foi a consideração do real nos conteúdos do ensino: "L'authentique a tenté de supplanter le didactique".

Caré esclarece:

Nous allons tenter d'imiter le réel; nous allons essayer de faire 'comme si' les choses étaient réelles, de simuler, mettant en place dans la classe les conditions d'un certain réalisme. (p. 50). 
No JdR não há necessidade de cenário, apenas de um espaço livre metafórico para a encenação na sala de aula. ( Caré, 1983).

O professor-animador deve, nessa atividade, estar sempre atento às tensões do jogo, sobretudo se o trabalho for desenvolvido com adultos; por isso, sugere-se que a tarefa sempre comece por exercícios preparatórios de relaxamento. No caso da pesquisa em questão, não houve muitos problemas com relação ao estímulo para a realização da atividade, porque o grupo era constituído de pré-adolescentes bastante participativos, conforme será visto no capítulo IV.

Segundo Caré (1983) o jeu de rôle tem um caráter híbrido por ser uma versão pedagógica do psicodrama moreniano. Trata-se de uma atividade que fica entre a fronteira do pedagógico e do terapêutico, o que possibilita ao professor um olhar mais atento às reações dos alunos, ao tipo de papel/ funções que eles preferem desempenhar, às relações de poder no grupo, etc. Caré nos adverte do perigo de a atividade pedagógica se transformar em sessão psicológica, a qual deve ser exercida por profissionais da área, capazes de administrar as emoções de seus pacientes. Isso não quer dizer que o professor deva evitar qualquer manifestação de emoção no jogo:

Le jeu de rôle est pédagogique, et le professeur de langue n'ayant pas de formation spécifique d'analyste ou de thérapeute ne peut prendre le risque de voir se développer une situation qui lui échappe. Mais un excés de prudence peut aussi avoir des effets négatifs." (p. 41)

Dufeu (1983) aponta algumas dificuldades na execução dos JdR:

- Alguns professores acham que esse tipo de atividade distancia o aluno do método ou manual adotado e assim ficam inseguros quanto a eficiência da aprendizagem realizada por meio do JdR.

- Alguns alunos podem achar igualmente difícil transformar o material lingüístico estudado em Jeux de Rôle; o reemprego do que foi estudado 
demanda reelaboração e tempo. Cabe ao professor então propor tarefas capazes de diminuir uma eventual ansiedade para que os alunos não fiquem tensos e sejam capazes de produzir produções espontâneas.

\subsection{A Simulação Global}

Le lieu-theme d'une simulation globale est un lieu édifiant d'apprentissage d'une langue et d'une culture, et de connaissance de soi et de l'autre." Francis Yaiche

A Simulação Global foi introduzida na França pelo Bureau d'Études pour les Langues et Cultures (BELC) e pelo CIEP de Sèvres em Paris, após a publicação de um artigo escrito pelo diretor do BELC, F. Debyser em 1973, onde ele proclama "a morte do manual e o declínio da ilusão metodológica". Entre 1973 e 1993, Debyser e seus assessores, entre os quais J.M. Caré, C. Estrade, F. Yaiche se dedicaram aos ateliês de criação do Belc no intuito de aperfeiçoar as técnicas de simulação no ensino-aprendizagem da língua estrangeira, tanto para os cursos de principiantes como para os cursos de alunos mais avançados. Seus idealizadores criaram, então alguns esboços (canevas, entre outros) para os seguintes temas: "o Hotel" , "o Circo" "o Cruzeiro", "o Hospital”, “ o Ônibus de Viagem”,"o Vilarejo”. Este último foi utilizado na pesquisa descrita no capítulo 4 .

Segundo Yaiche, (1994) a tendência a simulações, imitações, é inerente ao homem, o que nos remete a concepções do lúdico apresentadas no primeiro capítulo, sobretudo de Huizinga sobre o caráter ilusório do jogo, do "faz- de-conta" criado pelo jogo. Nesse sentido, existe uma relação entre a Simulação Global e o Jogo como tentaremos demonstrar. Com relação à simulação, Yaiche (1994, p. 42) afirma: 
Au fondement de l'acte d'apprentissage du petit d'homme (à travers la 'mimesis", la tendance à imiter, 'a simuler et á reproduire des univers et des modes de relation), la simulation constitue aussi un recours trés éprouvé dans le domaine des sciences et des techniques.

As técnicas de simulação são praticadas em inúmeros cursos de treinamento em diversas áreas, entre as quais as de ciências e tecnologia, como afirma Yaiche (1994). Busca-se, através de exercícios variados, possibilitar, aos participantes, vivência de situações diversificadas que os preparem para enfrentar novas situações na vida real. Os jogos eletrônicos concebidos para crianças e adolescentes buscam igualmente criar situações que os preparem para enfrentar situações não habituais. Todos esses recursos são utilizados para projetar situações e experiências ainda não ocorridas, mas que poderão surgir.

Como se pode constatar, a técnica da simulação é utilizada como um recurso do ensino-aprendizagem em vários campos do conhecimento. No caso específico do ensino de línguas, o grupo de estudiosos do Belc propôs técnicas de criação de um lugar-tema: o "Imóvel", o "Vilarejo", o "Hotel”, por exemplo assim como de personagens compondo esse lugar-tema.

Yaiche explicita melhor essa técnica (1994, p. 43):

Une simulation Globale est une méthode ou un complément méthodologique qui consiste à faire "débarquer" sur un lieuthème l'imaginaire d'un groupe d'élèves et plus particulièrement d'élèves en langue étrangère; un lieu qui est en même temps un thème (comme une île, un immeuble, un village, etc) sur lequel on va convoquer et fédérer toutes les activités d'expressions écrite et d'expression orale [...] . 
O autor diz ainda (p.44):

Une simulation globale a pour deuxième caractéristique de proposer à l'élève de jouer dans l'espace et dans le temps précontraints par l'enseignent en transitant par une identité fictive. Il s'agit pour lui d'abondonner dans la mesure $d u$ possible son identité réelle por entrer dans la peau d'un personnage ( ou rôle) de la simulation qu'il va incarner et "animer" ( au sens étymologique du terme: "donner une âme"). (p44).

Segundo Yaiche a Simulação Global consiste em um "como se". Em primeiro lugar, fazer com que o aluno viva dentro de um contexto escolar algo diverso. Em seguida, fazer com que esse aluno assuma uma nova identidade diferente da sua. Yaiche (1994, p.44) conclui:

Autrement dit, une simulation globale est une matière de faire entrer le réel dans l'univers de la classe, ce réel qui en est le plus souvent laissé à la porte et qui n'apparaît que d'une façon fantomatique, au mieux épisodique et donc désarticulé, au gré d'exercices ou de débats faits autour des questions existentielles.

É importante salientar que em suas publicações Yaiche definiu a simulação como uma experiência muito enriquecedora. Na pesquisa realizada, como veremos mais detalhadamente no capítulo 4, a Simulação Global teve o caráter de complemento pedagógico em virtude de procurar seguir o programa da escola e respeitar o cronograma e os temas e jogos sugeridos pelo método adotado pela instituição.

Com relação à Simulação Global, as questões que se colocam, entre outras, para os professores de língua estrangeira, são as seguintes:

- qual é a validade da técnica da Simulação Global para a fixação dos conhecimentos adquiridos; 
- os níveis desejáveis de sua aplicação, ou seja, debutante, médio ou avançado;

- sua aplicação deve-se dar como complemento pedagógico ou como constituindo um todo coerente e significativo?

Segundo Yaiche (1996, p. 70):

La simulation globale peut être considerée à bien des égards comme une mosaïque $d$ 'activités qui concourent à un projet global, la construction d'un lieu de vie, une sphère qui est en réalité une bulle $d$ ' imaginaire. Prises isolément, ces activités n'ont la plupart du temps aucun caractére ludique: il s'agit en effet d'écrire une biographie, un portrait de personnage, de composer un texte décrivant un paysage, une chambre, un immeuble, un hôtel,etc. Mais chacune de ces activités est sous-entendue par le postulat que l'on joue à " faire comme si", que l'on réprésente la vie, que l'on joue au jeu de la vie.

Para Huizinga (1996), todas as atividades humanas surgem de um jogo. E a Simulação Global serve de estímulo a esse tipo de atividade.

De acordo com Yaiche( 1996, p.71):

Le jeu a toujours été au coeur des interrogatinos sur l'homme. Le philosophe Huizinga démontre dans un brillant essai que I'homo est ludens avant d'être sapiens et que toutes les activités humaines sont fondamentalement structurées par le jeu.

Há uma estruturação do lúdico na Simulação Global que passa da Paidia, brincadeira, ao ludus, Jogo, da descontração à tensão. O árbitro dessa jogada é o ensinante, e os jogadores, os aprendentes. É a partir das regras e matrizes propostas pelo ensinante e graças a técnicas de animação que se estabelece em um primeiro momento a brincadeira, que passa quase que automaticamente ao jogo. 
Segundo Yaiche (1996, p.71):

En réalité la simulation globale est un jeu qui dans son principe est a play et dans son déroulement a game [...] la distinction entre game et play permet surtout d'opposer- comme fait Winnicott- les jeux rassurants parce que reglés, organisés, expliqués, prévisibles (games) et les jeux inquiétants, imprévisibles, effrayants même, ordre et désordre (play).

Na pesquisa, objeto de análise, partiu-se da criação de uma situação de relaxamento corporal, de sensações e impressões, longe de regras, para se chegar a propostas de criação de situações regradas, tais como a criação do "Vilarejo", etc.

A Simulação Global permite a inserção do mundo imaginário, do mundo do "outro", no mundo do aprendente. O jogo vai permitir um deslocamento e um enriquecimento cultural e humano sem que o aprendente saia do lugar onde se encontra. $\mathrm{Na}$ atividade descrita, o professor propõe que os alunos se desloquem para a cidade, de Boubolet, nome dado pelos alunos à cidade fictícia criada, situada no sul da França. Sugere depois que eles descrevam a cidade assim como seus habitantes $O$ deslocamento é imaginário. Nesse jogo o aluno assume uma nova identidade a partir de seu próprio ser físico e psicológico.

Segundo Yaiche (1996), na Simulação Global o "je est un autre" possibilita poder contemplar o reflexo da prórpria identidade na identidade de um outro.

Para Yaiche ainda (1996, p.73):

L'on sait, grâce à l'apport de la psychanalyse en éducation, que le désir de lire, écrire et compter sont des substituts du désir de comprendre et connaître un mystère dont l'enfant croit que seul l'adulte possède la clé. Grâce à certaines activités scolaires - 
et les simulations globales sont à notre sens de celles-là l'enfant a la sensation d'être initié aux activités des adultes, et peut-être d'accéder à leur monde. (p. 73)

Nesse jogo de vai-e-vem, de ser "eu" sendo também um outro, de ser o outro sem deixar de ser eu mesmo, vai-se construindo um novo universo lingüístico e cultural. É nesse espaço transicional, segundo Winnicott (1975), que se cria a confiança no jogo. O aluno não teme a alteridade, o que está fora, o desconhecido, ele se insere no novo universo inscrevendo-se enquanto sujeito aprendente, dono de seu desejo. Ele constrói o personagem, as produções desse personagem por ele criado, o espaço e as situações a ser vividos, etc, em um universo lingüístico novo no qual procura se inserir.

Yaiche afirma ainda (1998, p. 75) :

L'élève ne doit pas se sentir esclave, prisonnier ni même propriétaire de son rôle. C'est là peut-être toute la difficulté; mais dès l'instant où l'enseignant ne confond pas lui-même jeu et réalité, et qu'il garde le contrôle de sa classe, les éléves auront moins de risques de confondre jeu et jeu de rôle, réalité et apprentissage des rôles par le jeu.

A Simulação Global não é apenas uma técnica pedagógica ou um método para adquirir e aprender uma LE, mas, sobretudo, um recurso que permite ao sujeito resignificar as representações que tem do mundo a sua volta. Trata-se de sair de si para dar lugar ao outro, ao estranho, ao estrangeiro, ao desconhecido. Convém acrescentar que as crianças entram nesse mundo do faz-de-conta muito mais facilmente do que os adultos. A escola tenta cercear essa criatividade, tentando dirigir o caminho que o aluno deve seguir, nem sempre estabelecendo os elos necessários entre o sujeito aprendente e o mundo que o cerca. 
No entanto, como afirma Yaiche (1996, p. 76): "Vivre c'est se distinguer du monde, se dissocier de soi à soi, s'engager dans un processus schizique."

O autor diz ainda:

La classe de langue étrangère est un lieu de" haute schizie "puisque l'élève est engagé à mettre entre parenthèse sa langue maternelle (avec toute la charge émotionelle que cela suppose), et la compétence culturelle et de communication de "sa mèrepatrie."

Para Yaiche (1996), para aprender uma língua estrangeira é necessário achar a parte estrangeira dentro de si, o que de estranho reside em cada um de nós, para então reavaliar os conceitos que temos a respeito do mundo, da língua, do espaço e do tempo. O autor lembra que a Simulação Global é apenas uma entre outras técnicas de simulação, como os jogos de papéis - "jeux de rôles", o "drama”, etc.

Yaiche (1994, p.46) conclui:

La simulation globale est une technique"édifiante" et motivante qui permet aux apprenants de se décharger de leur charge existentielle en s'exprimant sous le couvert d'une identité fictive et en faisant oeuvre créatrice, oeuvre individuelle integrée dans une oeuvre de groupe. 


\section{Capítulo 4- A Experiência Lúdica com os Alunos de $7^{\mathrm{a}}$. Série}

\subsection{Uma Breve História da Instituição}

A escola eleita para a pesquisa foi o Liceu Franco-Brasileiro da cidade de São Paulo, onde trabalhei como professor de língua francesa no ensino fundamental, durante doze anos, de 1990 a 2002. A construção do estabelecimento iniciou-se em 1921, mas somente em 1923 inaugurou-se a Fundação que foi denominada inicialmente de Sociedade Civil Liceu FrancoBrasileiro. Somente em 1941 o colégio passou a se chamar de Fundação Liceu-Pasteur. A instituição, criada no início do século passado, teve como objetivo difundir o ensino da cultura e civilização francesas. As personalidades importantes desse período foram Georges Dumas e Ramos de Azevedo. Georges Dumas foi designado para vir à América do Sul a fim de procurar promover o ensino do francês tanto no nível secundário quanto no universitário.

A primeira sede do estabelecimento funcionou no bairro de Vila Mariana, bairro de classe média. Em 1964 foi inaugurada a segunda sede, na Rua Vergueiro, no intuito de oferecer o ensino de francês língua materna sobretudo aos filhos de franceses instalados provisoriamente ou por mais tempo no Brasil. O estabelecimento da rua Vergueiro segue até hoje o currículo oficial francês.

A língua francesa tem um destaque especial não só na unidade francesa, mas também na unidade brasileira, na qual o francês tem o status de língua estrangeira moderna. Atualmente, há quatro aulas semanais nas $5^{\mathrm{a}}$. e $6^{\mathrm{a}}$ séries e três aulas semanais nas $7^{\mathrm{a}}$. e $8^{\mathrm{a}}$. séries. No ensino médio há duas aulas de francês no $1^{\circ}$. ano. A partir do $2^{\circ}$. ano, o francês passa a ser facultativo em razão de o inglês ser a única língua estrangeira presente no principal vestibular do país: a Fuvest. Conviria lembrar que essa situação é 
recente. Antes, além de haver cinco aulas semanais de francês nas diferentes séries, as salas eram divididas em dois grupos, ficando cada professor com apenas 15 alunos na sala de aula, enquanto hoje são 35. Atualmente o francês é ensinado na $2^{\mathrm{a}}$. série do ensino fundamental com quatro aulas semanais.

Para melhor entender a diminuição da carga horária do francês no Liceu, devemos analisar a política do ensino de línguas estrangeiras no Estado de São Paulo. O francês a partir do final dos anos 80 , saiu da grade curricular do ensino público em virtude da introdução do ensino do inglês. A saída de diferentes línguas estrangeiras (alemão, italiano e francês) do vestibular da Fuvest em meados dos anos $90 \mathrm{fez}$ com que essas línguas ficassem em segundo plano no ensino secundário do Estado, uma vez que o vestibular é a grande preocupação e ambição do alunado brasileiro. Além disso, a política do Ensino do Francês Língua Estrangeira (FLE) , durante os anos 90, foi alterada por motivos diversos: o papel sociopolítico-econômico da França e dos países francófonos mudou muito na América Latina, e o espanhol, por causa da constituição do Mercosul, tornou-se a segunda língua estrangeira mais procurada no Estado de São Paulo. Foi o que aconteceu também no ensino fundamental e médio no Liceu, onde o francês perdeu uma aula semanal, atribuída a partir de então ao espanhol.

O Liceu Franco-Brasileiro, objeto da pesquisa, oferece um ensino na linha tradicional. Por volta dos anos 90 , sua linha de ensino sofreu alterações. Para garantir sua sobrevivência econômica houve flexibilização, não só na condução dos trabalhos das diferentes disciplinas, como também nas suas formas de avaliação. Isso não significa, entretanto, que o liceu passou a se enquadrar numa linha vanguardista de ensino. Hoje, o estabelecimento se coloca numa linha tradicional "afetiva", designação usada pela própria instituição. Com relação ao francês, o estabelecimento sofreu alterações em razão de questões mercadológicas. No final da década de 90 , aulas foram retiradas do francês nas $7^{\mathrm{a}}$. e $8^{\mathrm{a}}$ séries para ceder lugar ao espanhol, então introduzido nesse estabelecimento assim como em inúmeras outras escolas no Estado de São Paulo. 
Mas há um aspecto muito positivo relativamente à presença do francês no estabelecimento em questão, e motivo de muitas matrículas no liceu: o francofilismo de muitos pais de alunos que desejam para os seus filhos uma orientação pedagógica na linha francesa ou, pelo menos, a aprendizagem da língua francesa.

Assim, o francês ainda exerce um papel de destaque na instituição, com uma coordenação francesa ligada ao governo francês, que, a cada seis anos, envia um coordenador nativo para orientar o trabalho de seus professores. Até 1999, o liceu contava com a colaboração de dois professores franceses enviados pelo Ministério de Relações Exteriores Francês.

Ousamos esperar que uma eventual reintrodução de outras línguas estrangeiras no exame vestibular da Fuvest contribua para o aumento do número de aulas de línguas estrangeiras, assim como de francês no ensino fundamental e médio da rede pública e particular do Estado de São Paulo.

\subsection{O perfil da classe e dos alunos do liceu}

A clientela do liceu pertence, em geral, à classe-média. O público do liceu é geralmente constituído de filhos de profissionais liberais: médicos, advogados, engenheiros, administradores de empresa ou pequenos comerciantes da região, quase todos portadores de diploma do ensino superior e muitos deles são ex-alunos do liceu, o que explica o apreço que têm pelo colégio.

Por ser considerado um colégio com regras disciplinares rígidas, os alunos, em sua grande maioria, não apresentam grandes problemas de comportamento na sala de aula. As questões disciplinares mais corriqueiras 
são relativamente simples: conversas na hora da aula, "briguinhas entre amigos", "falta às aulas", o que não é nada grave no contexto escolar atual.

Os alunos do estabelecimento, de um modo geral, gostam do francês, adaptam-se e/ou gostam do professor que ministra a disciplina.

\subsubsection{A Classe objeto da pesquisa}

A classe analisada, uma das cinco classes da $7^{\text {a }}$ serie do estabelecimento e na opinião dos membros da equipe de francês, a melhor das classes - era composta de 33 alunos, que no final do ano se reduziram a 32.

Os alunos dessa $7^{a}$. série tinham, em geral, entre 12 e 13 anos. Todos os professores teciam elogios à classe, que se caracterizava por ser interessada, quieta e bastante cordial, o que favoreceu muito o trabalho realizado.

No primeiro bimestre os alunos não estiveram muito envolvidos com a língua francesa. Estavam desestimulados, em razão de problemas havidos no ano anterior, decorrentes da troca freqüente de professores ocasionada por doença da professora titular. Resolvi, então, utilizar o livro já adotado, para que os alunos se sentissem mais seguros, apresentar as lições que não tinham sido estudadas, e com isso ganhei a confiança da classe.

A classe, apesar de unida, era constituída de grupos distintos:

1 - Grupo A - composto por quatro meninas, que se destacavam não só pelo envolvimento com as atividades propostas como também pelo nível lingüístico empregado. Falavam o francês com bastante fluência. 
2 - O Grupo B - formado por quatro meninos também de muito bom nível caracterizava-se por um comportamento menos angustiado, menos tenso. Esses alunos eram considerados os "cds" da classe, termo então empregado para designar os alunos com rendimento escolar melhor do que os da média. É Interessante perceber diferenças de comportamento dos grupos A e B: as meninas eram mais tensas e preocupadas com o resultado obtido e os meninos mais descontraídos.

3 - O Grupo C - foi composto inicialmente de seis meninas. Uma das integrantes do grupo, entretanto, a Aluna $C$, logo no primeiro bimestre abandonou o grupo, o que a levou a ter de fazer todas as atividades, no decorrer do ano, sozinha. Não faltou convite para que a Aluna $C$, em questão, tímida, de excelente nível, entrasse em outro grupo, mas ela preferiu trabalhar de forma solitária. Ilustra o seu comportamento o relato que se segue: em uma das atividades propostas, uma simulação em vídeo, a aluna preferiu trabalhar com uma outra aluna, de nível excelente, mas do ano anterior, e não com uma colega de classe. A Aluna $C$ nunca aceitou interagir e trabalhar com o grupo do qual deveria fazer parte. Talvez devesse ter sido enviada ao serviço de orientação para uma análise de seu comportamento. É verdade que o grupo $C$, do qual a aluna em questão fazia parte, foi sempre um grupo problemático, sujeito a atritos, fraco lingüisticamente, instável em número (já que os alunos podiam mudar de grupo desde que não se adaptassem ao grupo).

4 - O Grupo D - era composto de quatro meninos bastante indisciplinados. Esses alunos gostavam de "brincar"

na sala de aula e não tinham um desempenho tão bom quanto o dos outros grupos. Aprendiam com facilidade, não tinham dificuldades lingüísticas, como o Grupo $C$, mas eram desorganizados e entregavam sempre os trabalhos com atraso. 
5 - O grupo E - era simpático, harmônico e interessado. Era o maior de todos, composto de 4 meninos e 3 meninas. O nível lingüístico era variado: havia meninos que falavam fluentemente o francês e outros que tinham dificuldades de expressão. Foi o grupo que mais recebeu dissidentes de outros grupos.

6 - O grupo F - composto de dois meninos e duas meninas, talvez tenha sido o grupo mais apático. Nele havia o Aluno $F$, que por ser filho de professor de francês e falar muito bem a língua, fazia todos os trabalhos sozinho, o que provocou reação negativa por parte de seus colegas. Como $\mathrm{F}$ tinha dificuldade pessoal em entrar em outros grupos (considerava o Grupo A muito fechado, o Grupo $C$ muito fraco e não era aceito em outros grupos) acabou ficando no Grupo F. Tinha temperamento egoísta, não era considerado bom companheiro, o que fez com que não fosse requisitado e aceito em outros grupos, apesar de seus conhecimentos lingüísticos. Em um concurso nacional sobre a francofonia, $F$ foi o único aluno do liceu escolhido para a grande final, onde obteve o quinto lugar.

7 - O grupo G - era formado por apenas dois alunos que acabaram ficando sozinhos, não aceitos em outros grupos por provocarem, em geral, tumulto e confusão nas atividades propostas.

No segundo semestre, um aluno transferido, sem conhecimento prévio do francês, entrou nessa sétima série. Apesar de não conhecer a língua estudada, acabou se envolvendo com o grupo, interessando-se pelas tarefas propostas. Foi o fotógrafo da grande maquete final da cidade de Boubolet, criada pelos alunos.

Enfim, as atividades de Simulação Global que serão descritas foram realizadas nessa sétima série, considerada a melhor das sétimas séries e caracterizada como tendo bom nível lingüístico. 
Quadro Geral dos Grupos da $7^{\mathrm{a}} . \mathrm{p}$

\begin{tabular}{|l|c|l|l|l|l|l|l|}
\hline Grupos & \multicolumn{1}{|c|}{ A } & B & C & D & E & F & G \\
\hline No.de meninos & 0 & 4 & 0 & 0 & 4 & 2 & 2 \\
\hline No.de meninas & 4 & 0 & 6 & 4 & 3 & 2 & 0 \\
\hline $\begin{array}{l}\text { Alunos } \\
\text { problemáticos }\end{array}$ & nenhum & nenhum & Aluna C & nenhum & nenhum & Aluno F & nenhum \\
\hline $\begin{array}{l}\text { Características } \\
\text { do grupo }\end{array}$ & $\begin{array}{l}\text { Fluente } \\
\text { Envolvido } \\
\text { Interessa- } \\
\text { do } \\
\text { Angustia- } \\
\text { do }\end{array}$ & $\begin{array}{l}\text { Envolvido } \\
\text { Interessado } \\
\text { descontraído }\end{array}$ & $\begin{array}{l}\text { Briguento } \\
\text { Desorgani- } \\
\text { zado } \\
\text { Tímido }\end{array}$ & $\begin{array}{l}\text { Indisciplina- } \\
\text { do } \\
\text { Imaturo } \\
\text { Facilidade } \\
\text { para }\end{array}$ & $\begin{array}{l}\text { Fo } \\
\text { Nível } \\
\text { Variado } \\
\text { Alunos } \\
\text { Dissiden- } \\
\text { tes }\end{array}$ & $\begin{array}{l}\text { Não } \\
\text { pontual } \\
\text { (tarefas) } \\
\text { ressado }\end{array}$ & $\begin{array}{l}\text { Imaturo } \\
\text { Alunos } \\
\text { Dissidentes }\end{array}$ \\
\hline briguento \\
\hline
\end{tabular}

Observação: o aluno 34 não aparece no quadro porque era aluno novo, nunca havia aprendido francês. Assistia às minhas aulas, mas aos alunos novos é oferecido um curso para principiantes - Francês Modular -- à tarde. É com esse outro professor que ocorrem as avaliações.

\section{3- O método "Café Crème"}

O método Café Créme foi introduzido nos cursos de francês do liceu há mais ou menos sete anos. O volume I do método é utilizado nos quatro primeiros anos do ciclo fundamental. O Café Créme 2 , foi adotado a partir de 2001, na $7^{\text {a }}$. série do ciclo fundamental. Na apresentação do método (v.1), os autores dizem que se trata de um método dirigido a um público-alvo formado por adolescentes e/ou adultos e que seu conteúdo é assimilável no período de 70 a 90 horas. Em sua grande maioria, segundo os autores, os textos e as gravações apresentadas são autênticos. A aprendizagem da língua se realiza 
segundo um processo de observação e dedução, havendo uma proposta de trabalho para o reemprego e memorização do que foi ensinado por meio de jogos (Jeux de Rôle) e, no fim, há uma recapitulação dos elementos da unidade. Segundo os autores, as unidades estão divididas respeitando a seguinte progressão: o aluno descobre e deduz o conteúdo dos enunciados e dos elementos nocionais-funcionais apresentados na parte "découvertes", depois sistematiza esse conteúdo em "boîte à outils" e se apropria dos elementos transmitidos em "culture en liberté", no final da unidade. Os autores tiveram a preocupação de mostrar os mais variados tipos de discursos quando escolheram o material a ser apresentado. Verificamos, nos diferentes volumes a presença de textos de tipo: informativo, argumentativo, explicativo e narrativo. Os autores ressaltam ainda que a aprendizagem deve se dar de forma dinâmica e interativa, e observando uma progressão gramatical rigorosa. Cada unidade é composta, em geral, da seguinte forma: apresentação de situações com textos e diálogos gravados em fita cassete e exercícios de compreensão das situações apresentadas. Em seguida, é apresentada uma situação que retoma a anterior ou os atos de fala apresentados, mas já com elementos da cultura e civilização francesa. Infelizmente, o método não contempla outras culturas francófonas além da francesa. A terceira parte, intitulada "lexique", retoma o vocabulário da lição, trabalhando algumas questões, geralmente de forma lúdica, quer em palavras-cruzadas, quer em charadas e/ou associação de palavras, etc. Essa parte visa a fixar e integrar o léxico no contexto global dos conhecimentos adquiridos.

A parte seguinte, intitulada "Grammaire" trata de vários tópicos gramaticais, mas não propõe um número razoável de exercícios capazes de levar o aluno a fixar os conhecimentos adquiridos. Assim sendo, são previstos exercícios suplementares para a fixação e assimilação dos elementos propostos. A última parte, denominada "Culture en liberté", é a síntese de tudo. Trata-se geralmente de dois diálogos visando à realização de exercícios de compreensão e expressão, que levam a uma produção escrita e a uma outra oral por meio de jogos, especificamente de Jeux de Rôle (JdR). 
Feitas essas observações, gostaria de fazer algumas considerações quanto ao uso do manual propriamente dito. Em primeiro lugar, é comum, no primeiro ano de uso do método que os professores trabalhem mais lentamente com ele, em razão da falta de conhecimento profundo do livro. Não é possível saber a priori quais serão as dificuldades encontradas pelos alunos. Assim, no ano da pesquisa conseguimos cumprir apenas as quatro primeiras unidades do livro, mais ou menos uma por bimestre. O livro 2 do método Café Crème é rico na apresentação dos aspectos culturais e civilizacionais da França.

No volume 2 , a parte "Culture en liberté" reserva um espaço ao cinema francês, com apresentação de trechos dos filmes, sobretudo do movimento "Nouvelle Vague". Nas unidades estudadas há referências especiais aos filmes de François Truffault.

O método Café Crème propõe em cada unidade, vários jogos de papel (Jeux de rôles) a partir dos atos de fala propostos na unidade. Essa proposta facilitou a elaboração das Simulações Globais propostas na pesquisa, atividade que será exemplificada a seguir.

Convém acrescentar que o método Café Crème não idealiza a cultura e a civilização francesa. Apresenta, isto sim, aspectos bastante realistas da vida cotidiana francesa.

O volume 2 do método adotado constituiu a linha diretriz da experiência realizada, propiciando atividades de Simulação Global que tinham como ponto de partida temas e sugestões de jogos já presentes no livro, o que permitiu manter elos de conteúdo com as demais quatro classes da $7^{a}$ série de outros professores, classes que não estavam tendo a experiência da Simulação Global . Assim as avaliações conjuntas exigidas pelo estabelecimento puderam ser observadas. Das três aulas semanais de francês da série da pesquisa, 
duas eram destinadas às atividades propostas pelo manual adotado e a terceira aos jogos e atividades de Simulação Global.

No nosso entender, as fichas que acompanham o vídeo do método são muito bem elaboradas e de grande valor pedagógico e civilizacional. A primeira unidade do vídeo do livro 2 retrata, por exemplo, o festival de Cannes e os filmes de Truffault, com as suas peculiaridades.

Convém lembrar que os objetivos gerais visados pela instituição no ensino da disciplina (compreensão e expressão oral e escrita do francês em situações da vida cotidiana, além dos elementos culturais do país) foram observados e mesmo estimulados através de jogos, que propiciaram a prática intensiva dos elementos lingüítico-discursivos apresentados nas lições. Os objetivos específicos visados na série (prática dos atos de fala propostos) foram trabalhados por meio de tarefas e exercícios continuamente retomados e praticados nos jogos de Simulação Global. As produções orais e escritas realizadas pelos alunos apresentaram um bom nível de elaboração e demonstraram que os alunos conseguiram atingir os objetivos de aprendizagem propostos, (a média das notas dos alunos foi em geral, sete). Parece-nos sobretudo importante ressaltar o interesse, o entusiasmo e a participação dos estudantes nas atividades propostas, elementos que garantiu os resultados obtidos.

\subsection{Relato das atividades de pesquisa realizadas em 2001}

No início do ano, como dissemos, havia 33 alunos na classe objeto da pesquisa. O exercício inicial proposto, que redundou na criação da cidade fictícia consistiu em um relaxamento nos moldes tradicionais. Os alunos permaneceram sentados com os braços cruzados sobre a mesa, o rosto colocado lateralmente sobre os braços, os olhos fechados, os pés plantados no chão, as pernas separadas. Os alunos deviam imaginar bolinhas gasosas 
entrando pelos seus pés, transformando seus corpos em um grande balão. Deviam imaginar que saíam pela janela da sala de aula e, lá no alto, avistavam o bairro onde estavam e, numa velocidade estonteante, cruzavam estradas, chegavam ao mar, atravessavam o oceano e entravam na África, primeiramente nas savanas e depois no deserto, observando a fauna e a flora locais. Em seguida, foi sugerido aos alunos que fizessem um passeio voando pelo mar Mediterrâneo. E que chegassem ao sul da França. Foram perguntados sobre o que estavam vendo. Tudo isso dito em francês. Os alunos disseram avistar uma cidade, que apelidaram depois de Boubolet. Foi-lhes solicitado que descessem e observassem de perto as características da cidade e que, ainda de olhos fechados, dissessem o que estavam observando, vendo e sentindo (olfato). ${ }^{3}$ As manifestações dos alunos eram feitas em francês.

Em qualquer aula há alunos mais extrovertidos, outros mais tímidos, por isso foi-lhes dito que, de vez em quando, haveria solicitações para que uns e outros respondessem às questões formuladas. O objetivo era fazer com que mesmo os alunos mais tímidos se exprimissem. Convém acrescentar que ainda assim, alguns alunos demoravam a encontrar uma resposta, quer por ansiedade que por timidez. Outros tinham receio de se exprimir por não saberem direito no que resultaria o jogo ou por não estarem habituados a esse tipo de atividade mais participativa. Pudemos, entretanto, perceber que depois do relaxamento os alunos se sentiram um pouco mais livres para se expor, para criar. Chegaram mesmo, depois do reconhecimento da existência de um vilarejo, a criar diferentes tipos de estabelecimentos, a imaginar o tipo de seus habitantes, de suas funções, a caracterizar o centro da cidade, sempre guiados pelas perguntas do professor. Seguem alguns exemplos de algumas das intervenções utilizadas:

3 Tive o prazer de conhecer pessoalmente Francis Yaiche, por ocasião de um colóquio da Aliança Francesa realizado em 2000 , onde ele se referiu a essa técnica de construção de um vilarejo. 
Professor : "Vous êtes en France maintenant et vous voyez un village au sud de la France? Vous voyez la mer?"

Alunos: "oui"

Porfessor: "Comment est la plage?"

Aluno: "Comment dit-on areia?"

Professor : "Le sable"

Aluno: "E escuro?"

Professor: "Foncé..."

Aluno: "Le sable est foncé".

Nesse pequeno exemplo pode-se observar como se dá a aquisição do vocabulário; o aluno é solicitado pela própria atmosfera do jogo a pensar em determinadas palavras, o que é bastante rico, pois o contexto cria o vocabulário básico a ser considerado, diferentemente de memorizações fora do contexto.

Em seguida, no mesmo jogo, os alunos deram detalhes sobre a atmosfera e as características da cidade: eles disseram que o céu estava claro, o mar agitado. Foi só então que os alunos criaram o nome da cidade.

Professor: "Vous voyez un panneau écrit: Bienvenue à..., c'est le nom de la ville. Quel est le nom de la ville?"

Aluna: "Boubolet."

Professor: "Vous autres, vous êtes d'accord?"

Alunos: "Oui."

Caillois afirma que o jogo, antes de qualquer coisa, é prazer. Jogamos pelo jogo em si. Houve sempre a preocupação de envolver os alunos na atividade proposta, fazendo com que eles se distanciassem da sala de aula e 
criassem um novo espaço. Com esse pequeno jogo de Simulação Global, os alunos se tornaram mais participativos. A cada resposta, que era por eles criada, a classe se empolgava e se apropriava do conhecimento. Segundo Alicia Fernández, isso demonstra que os alunos se tornam autores de seu próprio saber, e o produto desse saber foi, no caso específico, a criação da cidade Boubolet, autoria dos alunos, seu objeto de desejo. Os alunos desejavam, na realidade, criar um novo espaço - o da cidade por eles inventada.

Pode-se observar, na atividade realizada, uma maior freqüência no uso tanto de estruturas gramaticais e formas verbais aprendidas anteriormente, como do léxico das unidades anteriores. Os alunos conseguiram empregar de forma mais espontânea os elementos contidos nas lições estudadas, conseguiram ser mais autônomos na descrição dos ambientes, dos estabelecimentos comerciais escolhidos, e na caracterização dos habitantes da cidade.

A descrição do centro de Boubolet decorreu da seguinte forma:

Professor: "Vous êtes devant un établissement comercial, le centre ville est plein d'établissements comerciaux. Qu'est-ce que vous voyez?"

Aluno: "Un restaurant"

Professor: "Comment s'appelle-t-il?"

Aluno: "Le Poisson de Gabrielle."

Gabrielle era o nome de uma aluna da classe caracterizada pelo grupo nesse jogo como uma jovem de 19 anos, que trabalhava nesse restaurante com um outro garçon (Marcel) e uma garçonete (Elise). Os nomes dos personagens eram os dos alunos da classe, afrancesados. 
Professor: "Nous sommes au centre-ville. Qu'est-ce que vous voyez encore?"

\author{
Aluno: "Un kiosque à journaux?" \\ Porfessor: "Qui est le patron?" \\ Aluno: "C'est Nicolas." \\ Professor: "Quel âge a-t-il?" \\ Aluno: "Il a 30 ans." \\ Professor: "Il est comment?" \\ Aluno: "ll est gros et petit."
}

A idade dos personagens no jogo realizado foi aumentando gradativamente, demonstrando a constituição de um universo de níveis socioeconômicos diferentes e faixas etárias diferenciadas. $O$ último personagem criado foi um senhor de uns 60 anos, pai de três filhos (Júnior, Pierre e Jean), dono de uma locadora chamada Vidéo-club.. Esse senhor tinha também o nome de um dos alunos da classe, lan.

Quando foi solicitado aos alunos, depois da criação da cidade, que voltassem para a realidade da sala de aula, todos queriam falar ao mesmo tempo da experiência vivida. Todos estavam excitados. Um dos alunos perguntou: "Monsieur, qu'est-ce qu'on va faire maintenant?"

A classe foi dividida em grupos, e os alunos tiveram liberdade de escolher o(a) companheiro(a) que desejavam. Os alunos escreveram então frases, relembrando situações e emoções vividas, a partir de: "je me souviens de".

Os alunos deveriam relatar, a partir do enunciado "je me souviens de", a experiência vivida no jogo proposto. Não deveria ser apresentada nenhuma 
informação que não tivesse circulado durante o jogo. Tratava-se, na realidade, de um relato poético de lembranças, num ambiente de excitação, prazer e descontração. Estava assim definitivamente criada a cidade de Boubolet.

O próximo passo consistiu em fazer o recenseamento da cidade, criando o perfil dos habitantes, conforme orientação do próprio Yaiche em suas publicações. Foi solicitado então aos alunos que se conservassem em grupos e que cada grupo criasse o perfil de seis habitantes da cidade. Cada habitante deveria ter um nome, um sobrenome, uma determinada idade, profissão, características físicas, personalidade e outras informações que parecessem necessárias. Depois de distribuir as tarefas e determinar a profissão dos habitantes, os alunos acrescentaram outros dados. As profissões indicadas foram as mais diversas: médico, pedreiro, prefeito, ator, cabeleireira, farmacêutico, estudante, etc. Esse trabalho foi feito inicialmente sob a forma de rascunho na sala de aula, depois, em casa, sob forma impressa, para que os diferentes grupos tivessem o documento e participassem da criação dos personagens. Essa lista passada no computador foi depois utilizada por todos os grupos na criação dos diferentes jogos (JdRs) até o fim do ano escolar. Cada vez que os alunos tinham que fazer alguma atividade referente à cidade consultavam as listas para criar um jogo (Jdr), um jornal, escrever um e-mail. Estava criado o "lugar-tema" e "identidades-fictícias", que são os primeiros elementos para o jogo da Simulação Global, segundo Yaiche. A partir desse momento, a cidade criou vida e os personagens-habitantes, vozes. As produções, fruto das atividades desenvolvidas, eram todas conservadas em pastas. A análise dos trabalhos realizados no fim de cada bimestre permitiu verificar a aprendizagem obtida pelos diferentes alunos e grupos. Em caso de mudança de grupo, os alunos levavam para os novos grupos escolhidos, os trabalhos realizados.

Outra atividade desenvolvida no decorrer dos jogos foi a criação do mapa do centro da cidade de Boubolet, que redundou na apresentação de uma maquette de proporções gigantescas. 
A atividade foi realizada da seguinte forma: os quarteirões do centro de Boubolet foram inicialmente desenhados no chão pelo professor. Foram depois acrescentados, ainda no chão, por todos os participantes, os estabelecimentos e as instituições de Boubolet que se encontravam no centro da cidade. A seguir, alguns alunos designados pela classe passaram para a lousa o que tinha sido desenhado no chão. Esse desenho foi passado depois para uma cartolina e se transformou posteriormente numa maquete gigante, feita com caixas de papelão, que foi apresentada numa exposição no estabelecimento, exposição de grande sucesso que durou três dias e que foi visitada por professores, funcionários, alunos e pais de alunos. Os alunos pesquisaram na biblioteca do colégio, a arquitetura do sul da França onde se encontrava Boubolet. Respeitaram o tipo de teto das casas da região que é de ardosia. Os convites para a exposição foram elaborados pelos próprios alunos e escritos em francês.

Todas as atividades foram avaliadas de acordo com o sistema da escola, ou seja, através de notas. As atividades de Simulação Global geralmente valiam a metade da nota máxima, ou seja, cinco, e as mais trabalhosas, como vídeo, confecção de jornais, cartazes, revistas, valiam dez. As avaliações conjuntas com as demais 4 classes de $7^{a}$ série, previstas pelo regulamento da escola, continuaram. As atividades de jogos e Simulação Global, embora não previstas inicialmente pelos alunos, conseguiram plena adesão e interesse dos grupos, a tal ponto que eles perguntavam se num determinado dia não iria haver as atividades de jogos e expressão oral. As perguntas, o interesse, as solicitações mostraram o quanto a Simulação Global, o lúdico, repercutiu positivamente na participação da classe e na aprendizagem do francês. Assim, atividades lúdicas foram criadas no decorrer do ano, e tentou-se fazer com que os alunos participassem da dinâmica da sala de aula. Convém acrescentar que a partir de um dos textos do livro, sobre um festival de música numa cidade francesa, na primeira unidade do Café Crème 2, foi proposta a criação de um texto nos moldes do apresentado no livro, sobre um festival de música na cidade de Boubolet. Na unidade 3, na qual foram 
trabalhados problemas relativos às emissões de rádio, os alunos elaboraram numa cassete de áudio um programa de rádio na cidade de Boubolet, com entrevistas com os habitantes da cidade, informações jornalísticas, informações sobre o tempo e músicas ouvidas pelos seus habitantes. Os alunos fizeram, com base em sugestões oriundas da unidade 4, gravações em vídeo relativas à comemoração de aniversário de habitantes de Boubolet. Essa atividade foi desenvolvida fora do espaço de sala de aula, e os alunos trouxeram depois o vídeo realizado para ser visto pela classe.

Com relação à unidade 1 do livro que trabalhava "o encontro", os alunos relataram um encontro com os personagens da cidade de Boubolet. Foi sugerido aos alunos que relatassem diálogos de encontros de personalidades de profissões diferentes, tais como políticos, pessoas exercendo profissões liberais (dentista), pessoas propensas a se ocupar da vida alheia, etc. Esses diálogos, filmados pelo professor, foram depois apresentados na sala de aula, para que todos participassem das produções dos diferentes alunos e grupos.

A pesquisa, uma vez idealizada, teve a preocupação de observar os objetivos previstos no ensino/aprendizagem da língua estrangeira, assim como o cumprimento e observância dos elementos lingüístico-discursivos, pragmáticos, semânticos e fonéticos previstos no ensino/aprendizagem da série em questão.

O coordenador geral da área estava ciente de que a experiência prevista respondia aos objetivos gerais e específicos para a sétima série do ensino fundamental, num ensino-aprendizagem de ordem interativa e participativa.

A pesquisa realizada não teve a preocupação de quantificar o trabalho realizado, o seu rendimento em números, a quantidade de tarefas executada, mas a de observar e avaliar cada momento do processo vivido. A atuação do 
professor foi o de participante total, na concepção de Lüdke \& André (1988, p.28):

No papel de 'participante total', o observador não revela ao grupo sua verdadeira identidade de pesquisador nem o propósito do estudo. O que ele busca com isso é tornar-se um membro do grupo para se aproximar o mais possível da perspectiva dos participantes.

Na realidade, é o que foi feito durante a realização das atividades. 0 uso dos Jdr e da Simulação Global possibilitou uma integração profunda com o grupo, além da observância, prática e aquisição dos elementos nocionaisfuncionais previstos nas diferentes unidades do manual adotado. Os elos de conteúdo com as demais sétimas séries e as provas unificadas puderam ser mantidas. Todas as atividades propostas nas diferentes unidades do Café Créme 2 foram praticadas e recriadas no universo da cidade de Boubolet. A adesão e participação intensa dos alunos propiciou um grande entrosamento no grupo e a criação de um ambiente participativo extremamente favorável à interação e a prática da língua estrangeira.

Os alunos se pronunciavam sempre de forma positiva sobre as atividades propostas: "Monsieur, vamos fazer hoje os jogos e os diálogos das lições?" (para eles, um Jeu de rôle tinha a conotação de criar um diálogo dramatizado).

As aulas de francês são geralmente dadas em uma sala-ambiente do sub-solo, onde as carteiras estão dispostas geminadamente em cinco fileiras horizontais, diferentemente das salas tradicionais, onde as fileiras são verticais. Esse tipo de sala, onde as carteiras estão dispostas horizontalmente, modifica o tipo de relação e interação entre o grupo e também entre o grupo e o professor. Essa disposição favorece o diálogo e a comunicação entre professor e alunos, tornando as relações mais cordiais e democráticas. Muitas das atividades foram desenvolvidas não só nessa classe, mas também no pátio da 
escola, situado ao lado da sala de aula de francês. A descida para uma classe diferenciada, o uso do pátio, da escadaria, de outros pequenos locais aconchegantes davam aos alunos uma sensação de aula diferente, onde a liberdade e a participação tinham seu espaço garantido. A preparação das atividades em locais diferentes estimulou os alunos, mas pressupôs sempre a participação do professor, que circulava nos diferentes locais para verificar as dificuldades surgidas, quer de ordem morfo-sintática, quer lexical ou civilizacional.

Com relação à civilização, houve vezes em que foi necessário recorrer a informações de nativos:

Aluno: "Professor, como podemos fazer encomendas de salgadinhos na França? As padarias fazem bolos e salgados sob encomenda, sem que os preços sejam excessivos?".

Professor: "Não saberia dizer se isso é possível, mas vou me informar."

De posse das informações dadas pelo coordenador de Francês do estabelecimento, que é nativo, soube que as encomendas geralmente ocorrem em estabelecimentos especializados em festas.

A prática de jogos e Simulação Global na série escolhida propiciou o surgimento de situações não previstas, o que possibilitou reflexão sobre costumes e hábitos diferenciados e estimulou a aceitação de contrastes e diferenças não só linguísticas mas também culturais entre a França e o Brasil. 
Yaiche (1996, p.91) explicita:

C'est qu'en effet les simulations globales sont aussi un moyen d'approcher une civilisation (celle de la langue cible) et de mesurer ainsi les écarts de réprésentation ou de fonctionnement entre une culture et une autre. Mais elles peuvent être aussi les plaques sensibles révélant des situations économiques, politiques et culturelles taboues du pays dans lequel se passe la simulation globale." (p. 91)

Nos JdR e na Simulação Global, nem o professor, que é apenas um facilitador da tarefa, nem os alunos têm o controle do produto final do jogo, que é sempre um risco, característica do próprio jogo.

Segundo Dufeu (1983, p.43):

Le JDR décentre la relation pédagogique: le professeur n'est plus l'origine, le centre et l'aboutissement des activités linguistiques, il devient animateur, metteur en scéne discret et "soufleur". Les échanges sont centrés sur les interactions entre participants. La communication n'est plus orientée vers les contenus linguistiques mais vers la relation entre les interlocuteurs

O trabalho realizado no decorrer do ano interessou bastante os alunos e fez com que eles participassem ativamente das aulas, o que contribuiu para a construção de seu conhecimento da língua francesa. As aulas se enriqueceram sobremaneira com a participação dos alunos, para quem os jogos significavam não apenas a prática e assimilaçao dos elementos ensinados, mas uma interação entre alunos e professores e a criação de uma atmosfera de alegria, descontração e prazer. 
Com relação às atividades da Simulação Global, Yaiche assim se expressa:

Le contrat élève-école-parents qui se renouvelle chaque année est un contrat schizique ('sois un autre!') de double lien (' sois un autre tout en restant celui que tu es!'). Les enfants se livrent avec plaisir à ce 'frégolisme' identitaire parce que I'homo est ludens avant d'être sapiens et parce qu'ils voient dans le changement la possibilité de jouer avec eux-mêmes, avec leur image. De la même manière qu'ils jouent à la poupée, au papa et à la maman, ils jouent à l'élève et à la maîtresse ou au maitre. Mais certains enfants, on le sait, refusent d'aller vers ce monde qui est inconnu et vers cet inconnu d'eux-mêmes". (p.75)

\subsection{Comentários sobre o percurso percorrido nas atividades de Simulação Global}

O objetivo deste item é o de ilustrar e comentar algumas das etapas percorridas pelos diferentes grupos na construção do "Vilarejo", com a aplicação das técnicas da Simulação Global, assim como anunciar uma pequena mostra dos trabalhos elaborados e dos questionários respondidos, que serão apresentados em anexo.

Os objetivos específicos visados nessa experiência de aplicação de elementos lúdicos foram além dos já assinalados pelos diferentes autores que se pronunciaram sobre os jogos:

- a aquisição e/ou aperfeiçoamento de certas estruturas da língua falada e escrita, repertoriadas no manual adotado, assim como de elementos do universo sociocultural da França;

- a prática da língua em situações comunicativas;

- a prática de certos atos de fala habitualmente usados em situações correntes, tais como identificar/descrever, contar/imaginar/ argumentar, etc;

- dar um sentido à aprendizagem da língua estrangeira; 
- manter e desenvolver a interesse dos alunos pela aprendizagem da língua; francesa por meio de atividades prazerosas e interativas;

- desenvolver a autonomia do aprendente;

- desenvolver atividades inter-disciplinares

\subsubsection{Criação da cidade de Boubolet}

A descrição e caracterização da cidade, de seu centro comercial, assim como de seus habitantes exigiu a criação de um mapa, onde diferentes tipos de estabelecimentos foram lembrados e criados em francês. A caracterização dos habitantes da cidade possibilitou uma interação entre os diferentes grupos e a criação de personagens com nomes franceses, caracterização física, psicológica, idade, profissão, etc.

Inúmeros fôlderes, prospectos, foram criados pelos diferentes grupos, para mostrar as especificidades da cidade e incentivar habitantes da região a visitar Bouboulet, pelo caráter agradável do local e pelos programas interessantes que a cidade oferecia, com suas paisagens e possibilidades gastronômicas. Um dos fôlderes fazia alusão direta aos programas de cinema e teatro da cidade, assim como às especialidades dos restaurantes.

Alguns exemplos dessas produções estão na parte anexa deste trabalho.

\subsubsection{Diálogos praticados visando à aplicação de atos de fala aprendidos}

As produções orais dos alunos revelaram assimilação de atos de fala estudados nas lições. 


\subsubsection{Convites para a exposição final}

Alguns exemplos dos convites elaborados pelos alunos para a exposição final constam da parte anexa deste trabalho.

\subsubsection{Jornal da cidade}

Todos os grupos realizaram um jornal (Boubolet Express/ Express de Boboulet), no qual foram reproduzidos textos elaborados pelos diferentes grupos. As produções dos alunos versaram sobre os faits divers que tinham sido objeto de estudo na sala de aula.

\subsubsection{Atividades referentes às unidades 1, 2, 3 e 4 do método Café Crème 2}

A primeira atividade de Simulação Global baseada no método Café Creme 2 foi o vídeo realizado a partir do tema: O Encontro (La rencontre). Os jogos foram inspirados nos objetivos lingüísticos das unidades 1 e 2, ou seja, dar informações de si, tomar informações sobre alguém, informar-se e descrever (unidade1), entrar em contato com alguém, recusar-se a entrar em contato com alguém, expor um problema, pedir e dar conselhos (unidade 2). Conviria lembrar que o título das unidades 1 e 2 é La Rencontre. Os alunos realizaram, como atividades referentes a essas unidades diálogos de encontros na cidade já criada de Boubolet. A tarefa compreendeu 2 etapas, a primeira, de elaboração de um script e a segunda de apresentação oral dos diálogos elaborados aos colegas dos diferentes grupos.

A unidade 1 do método Café Crème tem também como objetivo o estudo do texto informativo. Foi então trabalhado em classe um texto sobre um festival realizado em Sully, proposto no manual adotado, o que permitiu aos alunos estudar as características do texto informativo e realizar depois exercícios de criação de textos informativos, inspirados no que tinha sido 
proposto no livro sobre um Festival de Musica no Brasil. Os diferentes grupos propuseram textos sobre um festival de Música em Boubolet.

A unidade 3, intitulada La Maison de la Radio foi o ponto de partida para a realização de uma série de atividades de Simulação Global, que teve como objetivos lingüísticos falar de si, fazer perguntas sobre a identidade de alguém e sobre seu percurso profissional, responder a perguntas, aprofundar a compreensão de textos informativos. O tema da unidade sugeriu a criação da Radio Boubolet. Assim como nas duas primeiras unidades, houve inicialmente a elaboração de um script e depois a gravação em uma fita cassete do programa que o grupo deveria apresentar na Radio Boubolet. As gravações feitas em cassetes foram apresentadas numa das aulas de Simulação Global aos colegas dos diferentes grupos. $\mathrm{Na}$ unidade 3 , na parte intitulada Expression., os autores do método adotado apresentaram ainda textos do tipo informativo, o que sugeriu aos alunos a idéia de criar cartazes, fôlderes, cartões, revistas culturais, com informações sobre a cidade de Boubolet.

Os objetivos lingüísticos da unidade 4 intitulada - L'Invitation (convite para uma festa de aniversário) convidar um amigo, aceitar um convite, pedir ajuda, aceitar e recusar uma ajuda - foram aplicados no trabalho solicitado, ou seja, na gravação em vídeo de uma festa de aniversário, que foi realizada em diferentes locais. Os próprios alunos escolheram os locais e prepararam a filmagem dessa atividade, nos moldes da experiência vivida na filmagem do "Encontro".

A exposição final, com a apresentação da Maquete Gigante no fim do curso, pretendeu comemorar uma experiência que, embora trabalhosa e nem sempre fácil, foi coroada de êxito do ponto de vista lingüístico-discursivo, civilizacional e humano, estimulando os alunos a se comunicar e a interagir em língua estrangeira na sala de aula. A experiência realizada confirmou a validade das hipóteses iniciais, ou seja, o interesse da prática de atividades lúdicas na sala de aula em meio institucional e o desbloqueio da expressão. Os erros cometidos eram apontados no fim das atividades da aula de aplicação da 
Simulação Global e depois comentados e sistematizados nas duas outras aulas do curso.

\subsubsection{Apreciação pelos alunos das atividades realizadas de Simulação Global}

As respostas completas constam do anexo desse trabalho

A avaliação completa dos depoimentos dos alunos também está na parte anexa desta dissertação. Apresento aqui apenas a seleção de algumas das declarações emitidas, com alguns comentários e/ou reflexões que confirmam as observações feitas sobre os jogos pelos diferentes autores citados nesta dissertação.

À questão formulada sobre o interesse da atividade realizada houve respostas bastante diferentes, a maioria de conotação positiva ("gostei", "adorei"), mas muitas também de caráter negativo (atividade "difícil", "trabalhosa", que exige muito tempo de elaboração).

Muitos gostaram da atividade e ressaltaram suas qualidades e características.A atividade foi considerada, pela maioria, como sendo "legal", "divertida", "interessante", "menos monótona". Os alunos constataram que a atividade possibilita a prática oral e escrita do francês, a aprendizagem do vocabulário, o exercício e o desenvolvimento da criatividade, a prática do francês em atividade mais descontraída.

Segundo grande parte dos alunos, os tipos de atividades que os jogos propiciam fazem com que o aluno se interesse pela matéria, prestando mais atenção e aprendendo mais. A atividade ajuda o aluno "a falar francês cada vez melhor".

Um tipo de aula como essa, dizem eles "é legal" por propor "atividades diferentes". A aula "não fica chata, cansativa, é bem legal". 
Os alunos apontaram também como aspectos positivos da atividade, ela propiciar um trabalho em grupo e incentivar a pluridisciplinaridade. Disseram eles, a propósito da criação da maquete apresentada na exposição final: "aprendemos francês e artes ao mesmo tempo".

Alguns alunos não apreciaram as atividades de Simulação Global, achando-a "monótona", "difícil". "chata" e "trabalhosa"

Os que gostaram das atividades ressaltaram o fato de elas propiciarem atividades diversificadas, como a redação de notícias policiais, o que os fez entrar em contato com uma realidade social diferente, dura, mas existente. Muitos alunos apreciaram a atividade proposta de elaboração de um programa de rádio.

Outro aspecto positivo lembrado por alguns alunos, foi a possibilidade de comparação entre aspectos culturais da França e do Brasil.

Muitos alunos reconheceram que, embora algumas atividades fossem trabalhosas, realizadas em pouco tempo e/ou em época inoportuna (elaboração da maquete na época dos exames finais, por exemplo), elas enriqueceram a experiência da sala de aula, mostraram novos caminhos. Alguns alunos se pronunciaram da seguinte forma: "bom para o futuro", "me ajudou muito a definir o que quero para o futuro".

O fato de os alunos terem apreciado a atividade não os impediu de verificar a dificuldade de se trabalhar em grupo, devido ao fato de que alguns dos integrantes dos grupos não trabalham, outros atrapalham e dificultam a seqüência prevista.

Por ocasião da construção da maquete os alunos fizeram pesquisas sobre a arquitetura da França, para saber qual a arquitetura dos estabelecimentos franceses do sul da França.

O caráter prazeroso da atividade foi ressaltado por grande parte dos alunos: "me diverti com as coisas que aconteceram", "foi engraçado". É "uma 
atividade diferente que descontrai a aula” ; " faz o aluno se interessar pela matéria", "nos libera daquela postura de aprendizagem quieta, escrevendo, corrigindo".

\subsubsection{Condução dos trabalhos}

\section{Correção dos trabalhos escritos.}

Como foi exposto na descrição das atividades de Simulação Global realizadas, das três aulas de francês da série, duas eram destinadas aos exercícios propostos pelo manual adotado, e uma para as atividades de Simulação Global. Os erros cometidos pelos alunos nas produções escritas dos alunos na aula de Simulação Global foram em geral comentados e sistematizados sobretudo nas duas outras aulas da série, depois de recolhidas as produções escritas.

Os erros cometidos que poderão ser vistos no anexo, uma vez que, para a exemplificação do trabalho realizado, mantive o texto original dos alunos, com os erros cometidos, foram de diferentes ordens: erros de morfossintaxe, de ortografia, de léxico. Convém lembrar a idade dos alunos, que era de 12 e/ou 13 anos.

Os erros de morfossintaxe mais correntes foram os de:

- concordância (masculino/feminino/ singular/plural): ex:” la mer est froid".

- emprego inadequado de tempos verbais : “quand j'ai dormi, j’ai un étrange revê."

-pessoas verbais erradas: pronome pessoal de $2^{a}$ pessoa, por exemplo, e verbo na $1^{\mathrm{a}}$ pessoa.

- concordância inadequada ex : "quand balles gaseuses sort".

- de adjetivos demonstrativos (Gênero, por exemplo): "cet manière", "cette festival".

- pronomes relativos: "ville que s'apelle" (emprego de que por qui ).

- pronomes pessoais: "trois fils que travaille avec il" (em vez de lui). 
- falta de contração da preposição com o artigo: "dans le centre de le village"

- elisões não feitas.

- ausência de determinantes antes do substantivo: "quand petits balles gaseuses"

- gênero de adjetivos indefinidos: "tous le monde".

- erros de ortografia: "buillees gasoses Atlaintic, Afric, momde"

- léxico: "elle est aute", "elle est base" (ela é alta, ela é baixa)

- preposições: "le festival a lieu em Boubolet"

- produção oral: Os níveis dos diferentes grupos eram bastante variados. Para não inibir as produções orais dos alunos, as correções eram feitas apenas no fim das apresentações.

Gostaria novamente de ressaltar o entusiasmo e o interesse dos alunos, que fizeram com que a aula se transformasse num ambiente agradável de interação e que houvesse prática real da língua e conseqüente comunicação entre os grupos e assimilação dos conhecimentos transmitidos.

\subsection{O Lúdico e a Prática Pedagógica}

Como se pode constatar pelo depoimento dos alunos, o jogo não é por eles considerado como uma atividade periférica, mas elemento central da aula, uma vez que cria situações comunicativas nas quais o aluno sente necessidade, vontade e prazer em se comunicar. Na realidade como diz Nicole Décuré, o jogo

peut servir constamment pour la pratique et le renforcement (acquisition des structures et du vocabulaire, création d 'automatisme), remplaçant ainsi les drills de laboratoire [...] (1994, p. 16)

Nicole Décure (1994) rebate a idéia de que jogar não é atividade séria.Tenta mostrar que pelo seu caráter livre, espontâneo e sedutor o jogo acaba implicando os alunos nas brincadeiras propostas e conseqüentemente 
nos atos comunicativos a ser praticados, ajudando a fixar estruturas e reforçando os automatismos estudados. A autora declara que, no seu entender, o jogo deve ser considerado como um trabalho produtivo e utilizado como tal:

Au-delà du clichê 'Jouer n'est pas travailler', le jeu en classe de langue doit au contraire être consideré comme un travail productif et utilisé tel quel. $(1994,18)$

O jogo, segundo Caré (1991) além de favorecer a fixação de palavras e de estruturas da língua, auxilia a assimilação de certas regras sintáticas da língua .

Plus interessante est l'idée que le jeu, mieux que beaucoup d'exercices, permet le maniement de certaines régularités de la langue. L'utilisation récurrente de mots ou des règles syntaxiques dans un jeu peut constituer une situation de communication plus authentique (même si le jeu est métalinguistique) que la répétition et la mémorisation par coeur du célèbre dialogue en situation, ou à plus forte raison que les techniques répétitives formelles telles que les exercices structuraux. (p.11-12)

Outro aspecto importante da aplicação dos jogos no ensino de LE e que aparece também no depoimento dos alunos é a da criação de um ambiente desconstraído que favorece a improvisação, a espontaneidade e a criatividade Nesse ambiente, confirmam os alunos, aprende se muito mais.

\section{Ainda segundo Caré:}

La líbération de l'expression trouve son terrain privilegié dans la simulation, les jeux de rôles et les jeux de théâtre, à condition que ce théãtre soit celui de l'improvisation, de la spontaneité, de la création, du gestue! "(1991, 12). 
A espontaneidade do ambiente faz com que o aluno se envolva nas situações criadas, se sinta mais a vontade para se exprimir, o que diminui sua tensão e favorece psicologicamente a apropriação de seus conhecimentos.

Jean-Jacques Favel (1994) lembra que a situação de comunicação espontânea provocada pelo jogo permite verificar, pela observação dos erros cometidos pelos alunos, a gramática que o aluno está se construindo da língua estrangeira:

Les jeux font intervenir des compétences variées, pas uniquement linguistiques. Ils sont toutefois un moment priviligié d'observation des erreurs commises en situation de communication spontanée." (p. 50)

Na realidade, os jogos estabelecem elos evidentes entre a sala de aula e o mundo (1994, p 22), fazendo com que o aluno não só aprenda a língua, mas também se enriqueça, à medida em que entra em contato com outra maneira de ver e sentir a realidade.

Caré (1991, p.7) relembra as contribuições importantes trazidas por estudiosos dos jogos, assim como por Winnicot :

Notre intention n'est pas de développer les théories de Winnicott qui trace ainsi les étapes génétiques de l'expérience créative, des premiers jeux transitionnnels à la relation au monde et à 'l'expérience culturelle', proposant ainsi une sorte de version psychanalytique des théories de Huizinga, ni même de nous demander si Winnicott n'éclaire pas d'un jour nouveau ce qui Piaget a dit du jeu et de la représentation symbolique. Ce qui nous frappe surtout dans ce qu'écrit Winnicott sur les objets et les jeux transitionnels, c'est qu'on peut sans métaphore,, l'appliquer à la parole (p.7)

E ainda : "La parole, en effet comme l'objet transitionnel est à la base "excitation orale et satisfaction" mais les "dépasse". (p.7) 
Nicole Décuré (1994, p. ) afirma: "Le jeu établit un pont entre la classe et le monde. Il crée une atmosphère de décontraction active. On s'amuse mais on travaille aussi." (p.22)

A prática dos jogos permite, pela incursão na realidade de outros países, um grande enriquecimento cultural.

A reflexão sobre contrastes, diferenças, aprofunda o senso crítico dos estudantes, seu poder de análise e de crítica.

Segundo Patrick Faugère (1994), não se trata apenas de passar de uma língua a outra, mas de uma maneira de ser no mundo a uma outra.

Sont alors en jeu non seulement les capacités d'apprentissage, le niveau linguistique, mais aussi ce qui régule les rapports humains, les valeurs, la façon de bouger, les mimiques, en bref tout le monde communicationnel. Une langue n'est pas neutre. (p.14).

Jean-Jacques Favel (1994, p. 50) afirma :

L'élement ludique est un moteur essentiel de l'apprentissage: il permet de provoquer une implication rapide des élèves, plus réelle et plus efficace (1994, p. 50) 


\section{Capítulo 5 - Conclusão}

A Simulação Global é um dentre os muitos recursos lúdicos utilizados no Ensino de LE. Na pesquisa em questão, a escolha dessa técnica foi de grande interesse, uma vez que possibilitou o estudo e a análise da função do lúdico no ensino/aprendizagem da língua estrangeira numa das séries do ensino fundamental de um estabelecimento da cidade de São Paulo. Convém acrescentar ainda que a técnica da Simulação Global constituiu um todo coerente com o material adotado no estabelecimento - o método Café Crème, que sugeria como atividade suplementar a criação de jogos que combinassem com os temas desenvolvidos nas unidades estudadas. Um outro elemento que justificou a escolha da Simulação Global foi o seu espírito de abertura e de criatividade.

A trajetória percorrida na experiência que se mostrou bastante rica revelou diferentes traços de personalidade dos alunos. Mas revelou igualmente a adesão do grupo à experiência que estava sendo realizada.

Ao aprender uma língua estrangeira, o aluno se constitui em sujeito. No contato com o Outro, com a alteridade, com o estrangeiro, com o que está do outro lado, com a diferença, com uma cultura diferente da sua, o aprendente se enriquece, retorna à sua cultura de origem com um olhar mais profundo, mais crítico, pois a cultura do outro, no caso específico a francesa, possibilita-lhe comparações, reflexões, não só sobre as duas línguas e as duas culturas, mas também sobre o problema da comunicação e da cultura em geral . Nesse contato com uma língua e cultura estrangeiras, o sujeito, além de desenvolverse intelectualmente, aumenta sua sensibilidade para o mundo que o cerca. $O$ indivíduo que aprende uma língua estrangeira, na verdade, envolve-se nela e com ela, acaba se constituindo de forma diferente, mais enriquecida. 
Yaiche (1996, p.78) afirma:

Le chemin qui conduit l'individu d'une culture vers un individu d'une autre culture n'est donc pas toujours aussi longs que certains le croient. Car l'étranger est autant I'"étranger à nous-mêmes" que l"etranger de soi-même. La diversité n'implique pas nécessairement la différence et les diversités d'expression culturelle se rejoigent dans le sens où elles expriment le même réel.

Num tipo de atividade envolvente como a que foi proposta, acredito que o aprendente passa a desejar apropriar-se do conhecimento veiculado pelo mestre. Convém acrescentar que esse conhecimento o constituirá, quando transformado em saber. Esse saber, dependendo do aprendente, poderá ter conotações bastante variadas, o que mostra a riqueza da aprendizagem da língua estrangeira. .

Yaiche afirma:

La simulation globale fait approcher l'idée que l'on peut être acteur de son destin, constructeur de son identité, responsable de son "Moi". L'identité, on le sait, se développe en différentes phases et à partir d'identifications à des modèles. Ce processus d'identifications multiples ( et à répétition) contribue à créer une identité idéale, modéle parfait du " Soi" auquel aucun aspire et se tâche de se conformer" ( $p .78)$

As aulas nas quais as simulações globais foram aplicadas decorreram num ambiente agradável de descontração e prazer, embora tivesse havido momentos de tensão, quer de ordem psicológica, em razão de problemas entre os grupos (timidez, falta de iniciativa por parte de alguns alunos, atitude de superioridade de outros, rivalidade entre os grupos, desejo de alguns alunos de sobressair-se, não concedendo a palavra ao Outro), quer de ordem lingüística (diferença de nível de expressão oral e escrita entre os alunos). Os alunos, em sua maioria, demonstraram, entretanto, uma atitude de colaboração, de alegria de aprender o francês. Acredito que isso se deva, em parte, ao clima 
propiciado pelo lúdico, pelo emprego do jogo na aprendizagem do Francês. Sem querer fantasiar, diria que a disciplina propiciou aos alunos no ambiente criado pelo lúdico, uma Aula Feliz, além de solidificar conhecimentos de ordem linguística e cultural.

A aula lúdica ainda é vista, na maioria das instituições educacionais e familiares, como algo não sério.

Dufeu (1983) esclarece:

Certains professeurs ont peur de perdre leur temps en proposant des activités qui s'écartent du manuel et sont insécurisés par une progression qui ne correspond pas à des critères traditionnels. Le manque de congruence entre leur action pédagogique et leur conception de l'apprentissage se reporte sur le jeu lui-même et sur l'engagement du groupe. ( p. 44)

Durante a experiência, a adesão do grupo foi total, o que possibilitou resultados encorajadores e expressivos. As produções foram sempre resultado de trabalhos individuais e/ou em grupo efetuados depois de pesquisa e de reflexão, quer de ordem lingüístico-discursiva, quer de ordem cultural.

A função do professor foi sempre a de abrir caminho para que os próprios alunos pudessem exprimir seu saber e sua criatividade. Eles se apropriaram de seus conhecimentos, foram "autores" de seus trabalhos, segundo a terminologia de Alicia Fernández. As atividades de francês, prazerosas, agradáveis, estimulantes, na própria expressão dos alunos, foram fruto da atmosfera de amizade, colaboração, interação, havida no grupo e propiciada pelo emprego do lúdico. 


\section{Bibliografia:}

BÉRARD, E. L'Approche Communicative: théories et pratiques. Paris: Cle International, 1991

BLÜHDORN, Hardarik. "O discurso sobre o real e o virtual - uma abordagem semiótica".In Pandemonium Germanicum. São Paulo: n², DLM FFLCH/USP, 1998. p. 229-255.

BOGAARDS, Paul. "Attititudes et motivations: quelques facteurs dans l'apprentissage d'une langue étrangère". Pays-Bas: Université de Leiden. p.38-44.

BOSSA, N. A. A Psicopedagogia no Brasil: contribuições a partir da prática, Porto Alegre: Artes Médicas, 1994.

CAILLOIS, Roger. Les Jeux et les hommes - le masque et le vertige. Paris: Édition Gallimard, 1958.

CARE, J.M. "Simulations globales et productions romanesques" In Le Français dans Le Monde: apprendre les langues étrangère autrement. Baume-lesDames: I.M.E, jan. de 1999.

"Dramatisation et Simulation" In Français dans le Monde no. 123 Paris: Hachette/Larousse, 1976.

"Jeux drôles ou drõles de jeux" In Français dans le Monde 176, Paris: Hachette/Larousse, 1983.

"Approche Communicative: un second souffle?" In Français dans le Monde 226, Paris: Edicef, 1989.

CARE, J.M. \& DEBYSER, F. Jeu, Langage et Créativité: les jeux dans la classe de français. Paris: Hachette, 1991.

CORMANSKI, A. Le Corps dans la Langue: les techniques dramatiques dans l'enseignement/apprentissage des langues étrangères. Thèse de Doctorat, Paris: Université de la Sorbonne Nouvelle - Paris III, 1993.

DEBYSER, F. "Simulation et réalité dans I'enseignement des langues vivantes" In Français dans le Monde no. 104, Paris: Hachette/Larousse, 1974.

"Dramatisation, simulation, jeux de rôles" In Français dans le Monde no. 123, Paris: Hachette/Larousse, 1976.

DECURE, N. "Jouer? Est-ce bien raisonnable?" In Le Jeux - Les Langues Modernes, Paris,1994. 
DUFEU, B. "Le jeu de role: répères pour une pratique. In Français dans le Monde no. 176, Paris: Hachette/Larousse, 1983.

"La relaxation en Pédagogie" In Français dans le Monde no. 229, Paris: Edicef, 1989.

FAVEL, J.J. "De la culture au primaire: des jeux culturels dans la classe d'anglais au cycle III de l'école élémentaire" In Les Langues ModernesLes Jeux, Paris, 1994.

FAZENDA, I (org.). Novos Enfoques da Pesquisa Educacional, São Paulo: Cortez Editora, 1992.

FERNÁNDEZ Alicia. A Mulher Escondida na Professora: uma leitura psicopedagógica do ser mulher, da corporalidade e da aprendizagem. Trad. de Neuza Kern Hickel. Porto Alegre: Artes Médicas, 1994.

A Inteligência Aprisionada: abordagem psicopedagógica clínica da criança e sua família. Trad. Iara Rodrigues. Porto alegre: Arte Médicas. 1991.

"Grietas, Poesia y Humor...Fisurando El Aburrimiento" in E.Psi.Ba, no 2, Buenos Aires: E.Psi.Ba.

"Pensar la Alegría. Aún de la Pensar" in E.Psi.Ba, no 3.

Buenos Aires: E.Psi.Ba

O Saber em Jogo: a psicopedagogia propiciando autorias de pensamento, Porto Alegre: Artes Médicas, 2001.

Psicopedagogia em Psicodrama; morando no brincar,

Petrópolis: Ed. Vozes, 2001.

FREUD, Sigmund. "Lo Inconsciente" in Obras Completas, Vol. 2 Madrid:

Editorial Biblioteca Nueva, 1981. p. 2061-2082. . La Vie Sexuelle. Paris: Puf, 1969.

GARCIA-ROZA, L. A. Freud e o Inconsciente, Rio de Janeiro: Jorge Zahar Editor, 1994.

GERMAIN, C. Évolution de I 'Enseignement des Langues 5000 ans. Paris: Cle International, 1993.

L'Approche Communicative en Didactique des Langues. Québec: CEC, 1993-B.

GIORDAN, A. Apprendre! Paris: Belin, 1998 
HUIZINGA, Johan. Homo Ludens. Trad. João Paulo Monteiro. São Paulo: Editora Perspectiva, 1996.

KUNDMAN, M. Sabina. Ensinando e Aprendendo Francês em nível universitário. Tese de Doutoramento. São Paulo: FFLCH-USP. 1994.

KUPFER, M. C. Freud e a Educação: o mestre do impossível. São Paulo: Ed. Scipione, 1989.

LAJONQUIĖRE, L. De Piaget a Freud: a (psico)pedagogia entre o conhecimento e o saber. Petrópolis: Ed. Vozes, 1993.

LÜDKE, M \& André, M. E. D. A. Pequisa em Educação: abordagens qualitativas, são Paulo: E.P.U,1988.

MARTINEZ, P. La Didactique des Langues Étrangéres. Paris: PUF, 1998

NARCY, Jean-Paul. Apprendre une Langue Étrangère: didactique des langues: le cas de l'anglais. Paris: Les Éditions d'Organisation, 1990.

NOVAES, A. O Desejo. São Paulo: Cia . das Letras, 1990.

PAÍN, S. Subjetividade, Objetividade: relações entre desejo e conhecimento. São Paulo: Cevec, 1996.

ORLANDI, E. P. "Tipologia de discurso e regras conversacionais". In $\underline{A}$ Linguagem e seu Funcionamento. São Paulo: Ed. Pontes, 1996.

PIAGET, Jean. Six Études de Psychologie. Paris: Éditions Denoël, 1964.

PICCINI, A. P. Freud. São Paulo: Ed. Moderna, 1986.

PORCHER, L. "Motivations ou raisons d'apprendre". In Bulletin de l'Association des professeurs de Langues Vivantes. Paris: 1985 p. 105-112.

POSSENTI, S. "Um cérebro para a linguagem". In Boletim da ABRALIN. São Paulo, 13, dez/92, p.75-84.

PUREN, C. - Histoire des Méthodologies de l'enseignement des langues. Collection Didactique des Langues Etrangères. Paris: Nathan/CLE International, 1988. La didactique des langues à la croisée des méthodes. Essai sur l'éclectisme, Paris: Didier, 2000.

RODRIGUEZ, C. M. "Afetividade e inconsciente na didática de línguas" In D.E.L.T.A. São Paulo, vol.10, no 1, fev/94. p. 07-19.

SILVA, Adriana Pucci Penteado de Faria. Tecendo o jogo: a mão da abordagem lúdica no ensino de italiano como segunda língua. Dissertação de mestrado. São Paulo: FFLCH/USP, 1998. 
SEVERINO, Antonio Joaquim. Metodologia do Trabalho Científico. São Paulo: Ed. Cortez, 1996.

VISCA, Jorge. Clínica Psicopedagógica: epistemologia convergente, Porto Alegre: Artes Médicas, 1987.

WINNICOTT, D.W. O Brincar e a Realidade. Trad. de José O. Aguiar e Vanede Nobre. Rio de Janeiro: Imago Editora Ltda, 1975.

Explorações Psicanalíticas, Porto Alegre: Artes Médicas, 1994.

- O Ambiente e os Processos de Maturação: estudos sobre a teoria do desenvolvimento emocional, Porto Alegre: Artes Médicas, 1990. . A criança e o seu Mundo, Rio de Janeiro: Guanabara Koogan Ed., 1982.

WEISS, M. L. L. Psicopedagogia Clínica: uma visão diagnóstica, Porto Alegre: Artes Médicas, 1994.

YAICHE, F. Les Simulations Globales: mode d'emploi, Vanves, Paris: Hachette Fle, 1996.

"Les Simulations Globales" In Les Langues Modernes no. 2. Paris: APLV, 1994. 


\section{Bibliografia Complementar:}

DELANOY, C. La Motivation: désir de savoir, décision d’apprendre. Paris: Hachette, 1997

FRANÇOIS, Frédéric. Teorias \& Práticas: Práticas do oral. Trad. de Lélia Erbolato Melo. Carapicuiba: Pró-Fono Departamento Editorial, 1996.

GAONAC'H, D. - Théories d'apprentissage et acquisition d'une langue étrangère. Collection LAL, Paris: Hatier-CREDIF, 1987.

MOIRAND, S. - Enseigner à communiquer en lanque étrangère. Hachette, Paris: 1982.

NOVAES, A. O Desejo. São Paulo: Cia das Letras, 1990.

PÊCHEUX, M. Semântica e Discurso: uma crítica à afirmação do óbvio. Campinas: Editora da Unicamp, 1988.

PUREN, C. .- La didactique des langues à la croisée des méthodes. Essai sur l'éclectisme, Paris, Didier, 2000.

TARDIF, Jacques. Pour l'Enseignement Stratégique: L'Apport de la Psychologie Cognitive. Montréal (Québec): Les Éditions Logiques, 1992.

TROCMÉ-FABRE, H. - J'apprends, donc je suis: introduction à la neuropédagogie. Paris: Editions d'organisation, 1992.

WITTGENSTEIN, Ludwig. Tractatus Lógico-Philosophicus. Tradução de Luiz Henrique Lopes dos Santos. São Paulo: Edusp, 1994. 
ANEXOS 


\section{ÍNDICE:}

ANEXO I - Apresentação dos alunos sobre as Atividades de Simulação Global desenvolvidas

ANEXO II - Questionário: A classe em relação às línguas estrangeiras ANEXO III - Questionário Final

ANEXO IV - Tableau des contenus - Café Crème 2

ANEXO V - Perfil dos habitantes de Boubolet

ANEXO VI - ANEXO VII - Jornal: Boubolet Express

ANEXO VIII - Textos Referentes à Atividade: Festival de Música

ANEXO IX - Mapa da Cidade.

ANEXO X - Convites para a Exposição Final.

ANEXO XI - Fotos da Maquete Gigante. 


\section{ANEXO I - Apresentação dos alunos sobre as Atividades de Simulação Global desenvolvidas.}

\section{Atividade : Faits-divers}

Pergunta: Você gostou da atividade? Sim ou não? Por que?

- Sim, achei muito legal, pois ajuda nosso vocabulário.

- Sim porque além de dar um ar jornalístico e diferente é ótimo exercício de desenvolvimento da criatividade.

- Sim, eu gostei, pois fizemos um texto que fala sobre acontecimentos atuais e que não são raros.

- Sim, porque é uma coisa diferente, legal.

- Sim, porque com isso praticamos e aprendemos mais o francês.

- Sim, porque é diferente e da hora. (sic)

- Sim, porque com isso podemos aprender e praticar melhor o francês.

- Sim, porque é diferente.

- Sim , porque é melhor que prova..

- Sim , porque isso faz com que aprendamos e discutamos e isso nos estimula nossa criatividade.

- Eu gostei, porque assim, exercitamos nosso francês em uma atividade mais descontraída. Não gostei muito porque a notícia era com sangue, mas tudo bem.

- Sim porque é uma coisa diferente e também treinamos nossa escrita em francês. 
- Sim, porque é melhor que ter aula normal, é mais dá hora e aula normal eu não entendo nada. (sic)

- Sim, porque faz com que aluno se interesse pela matéria.

- Sim, porque é bom trabalhar em grupo.

- Sim , porque é uma coisa diferente que sai daquele ritmo de matéria todo dia. É mais divertido aula assim, a gente presta mais atenção e aprende mais.

- Sim porque os alunos criam criatividade e vontade de achar as coisas para o trabalho. E é bom demais e ganhamos notas em grupo.

- Sim, porque é uma atividade que nos mostra um " pedaço" do cotidiano não só Francês, é é muito "real", um fato.

- Sim, é um trabalho diferente que eu tinha curiosidade.

- Sim, porque nos mostra uma profissão que é o jornalismo e ajuda a gente a ver as profissões que existem.

- Sim, porque nós não estamos só fazendo exercícios gramaticais e sim mais exercícios orais. E esse tipo de exercício nos ajuda a falar Francês cada vez melhor.

- Sim, pois eu sempre quis fazer algo relatando crimes, a escritora que eu mais gosto é Agatha Cristie, pois você tem que desvendar os casos dela. Adoro romance policial.

- Sim, adorei é bom para o desenvolvimento, distração. Também é bom porque é diferente e não fica uma aula chata, cansativa, é bem legal.

- Sim, porque é legal fazer atividades diferentes. Essa atividade tem que usar criatividade e eu adoro fazer esse tipo de coisa.

- Sim, porque trabalho em grupo é da hora. (sic)

- Sim, porque aprende realmente como se faz um jornal e como se elabora uma notícia. 
- Sim, porque eu gosto de fazer esse tipo de coisa.

- Sim, pois é uma atividade diferente, fazer uma notícia, imaginar com quem aconteceu, mas nunca saindo da cidade de Boubolet ( que é uma cidade imaginária, assim como tudo o que nela há) e usando a criatividade sempre, aprendendo Francês ao mesmo tempo.

- Eu achei muito legal e interessante, eu adorei. Achei esta idéia de escrever uma manchete sobre uma coisa real ( um acidente, assalto,...) foi muito boa! Pois a vida não é só coisa boa, nós não vivemos dentro de uma bolha, onde tudo é perfeito. Existe coisas boas e ruims e nós temos que conviver com isso e acho que com este trabalho nós vamos aprender mais e ficar sabendo que a vida não é só diversão. 


\section{Atividade : Radio Boubolet}

Pergunta: Você gostou da atividade? Sim ou não? Por que?

- Sim, foi uma atividade diferente, legal, mas também muito trabalhosa, se for para fazer de novo eu não gostaria, apesar de ter sido legal, mas o trabalho que deu não compensa.

- Eu gostei, mesmo com alguns problemas e discussões. Foi bem divertido e descontraído, algumas pessoas não fizeram grande coisa. Também gostei, porque foi uma experiência nova e diferente para mim, aprendi algumas coisas.

- Sim , adorei. Eu adoro atividades em grupo. E a nossa Radio ficou muito engraçada.

- Sim , mas dá muito trabalho, prefiro vídeo.

- Sim, adorei, porque é um pouco engraçado fazer trabalho em grupo.

- Sim, adorei demais, um pouco difícil, pois era engraçado.

- Sim, porque é uma atividade diferente. Mas a da festa de aniversário podia ter outro tema.

- Gostei, pois novamente treinamos nosso francês de forma diferente, porém um pouco difícil. Gravar em voz alta, se preocupar com a palavra, som , etc. sinceramente, nunca quero ser locutora! Mas adorei a atividade e espero fazer outras parecidas.

- Eu gostei, porque é uma coisa que nunca tínhamos feito antes. Foi uma experiência legal... Gostei muito. O mais legal é que foi em grupo. Cada um fez sua parte, foi $d+$ ! Adorei monsieur! (sic)

- Não, porque se eu tivesse um gravador daria para fazer.

- Mais ou menos, pois exige equipamentos que nem sempre as pessoas têm, mas é mais legal do que os trabalhos escritos e muito objetivos.

- Eu gostei mais das outras atividades de Boubolet.

- Sim, é muito interessante, mas o prazo de entrega poderia ser maior porque eu não tenho gravador.

- Sim, mas dá muito trabalho e tem pouco tempo.

- Sim, porque é uma experiência nova. 
- Sim, é interessante fazer atividades diferentes! Principalmente quando você escuta bastante radio, você tem curiosidade de saber como é, e nós fizemos isso, vimos uma realidade que eu nunca tinha visto, ser, tipo, locutor de radio!

- Sim, é muito divertido participar das atividades de Boubolet e a radio foi muito interessante. È uma forma diferente e legal de aprender. Nós tivemos que pesquisar também coisas que aparecem nas rádios francesas, nos trazendo cultura.

- Sim, porque eu sou muito envergonhado e assim eu estou perdendo a vergonha.

- Sim, porque nos ajuda a interpretar melhor a fala e a audição em francês.

- Sim, eu achei muito interessante e divertido fazer uma radio francesa.

- Sim, porque é uma forma legal de desenvolver um trabalho de grupo! Gostei “ mucho”! (sic)

- Eu gostei, mas deu muito trabalho, foi muito difícil.

- Sim, pois eu aprendi um pouco sobre o dia a dia em uma radio. Isso também melhorou meu vocabulário, pois aprendi muitas palavras que não sabia.

- Sim, porque foi engraçado.

- Sim, é bem legal, mas dá muito trabalho.

- Não, pois deu muito trabalho para fazê-la

- Sim, eu gostei, pois foi um trabalho diferente, sempre fazemos diálogos, filmagens, etc... Gravamos nossa voz, do jeito normal e diferente (como por exemplo, a cozinheira que fez uma voz diferente). O único problema desses trabalhos são os gupos, pois sempre tem alguma confusão. Mas , o trabalho em si, é muito bom. 
Atividade: Fête d'anniverssaire

Apreciação dos alunos sobre a atividade:

Pergunta: Você gostou da atividade? Sim ou não? Por que?

- Sim , pois foi interessante divertido e deu a idéia de como é um aniversário francês, mesmo sendo difícil na parte de filmagens por causa de problemas com a câmara, o trabalho foi muito bom.

- Sim porque é muito melhor do que prova

- Não, porque esse trabalho foi mais chato do que os outros.

- Não, pois o tempo foi curto para fazer o trabalho sendo que era uma coisa difícil.

- A atividade é legal, mas se feita com pessoas responsáveis e legais também.

- Não muito. Eu fiz na sala de aula. Uma atividade legal.

- Não porque foi muito bobo, sem graça, repetitivo porque todos, alguém está fazendo aniversário, podia ter sido situações diferentes.

- Não porque tivemos pouco tempo para fazer.

- Não porque duas pessoas não fizeram e deu briga com o grupo, porque tive que pegar a fita com uma menina e o resto das meninas não fizeram nada e sempre davam uma desculpa para ir antes embora, mas fora isso muito engraçado fazer um aniversário

- Eu achei legal porque a gente falou francês e aprendeu mais vocabulário

- Eu adorei esta atividade, acho muito interessante e menos monótono, sai da rotina de ficar estudando sentada na classe. Acho que estas atividades além de serem divertidas e interessantes, fazem você conviver com um grupo. E isto é muito bom para o futuro. Acho que estes trabalhos, fora da rotina nos dão estímulo. 
- Não porque teve muito pouco tempo para faze-lo.

- Não eu não tenho a câmera e nem tempo suficiente para fazer o trabalho. $O$ tempo também foi curto. $O$ senhor tem idéias bem legais, mas não dá para fazer de uma vez só.

- Não porque eu não tinha câmera.

- Sim, pois eu adoro filmagens.

- Gostei, mas achei difícil gravar, como sempre o som é que é complicado de aparecer. Porém adorei, pois aprendemos, exercitamos o francês de maneira diferente.

- Sim foi muito divertido fazer o vídeo, é uma forma diferente e interessante de aprender.

- Achei bem interessante, porque não fizemos apenas uma festa de mentirinhas, mas sim uma festa com bolo, brigadeiro, refrigerante..., tudo de verdade. Aproveitando a ocasião para fazer uma festinha. Esse tema super legal porque podemos fazer uma história com bastante criatividade e não uma história rotulada.

- Sim, pois eu gosto muito de atividade com o vídeo, é legal.

- Sim, eu gostei, mas foi complicado de montar.

- Sim, pois nós aprendemos como expressar melhor na frente dos outros.

- Sim, foi muito difícil. Prefiro outro tipo de atividade, mas em geral achei bem legal.

- Sim, pois são poucas vezes em que fazemos uma atividade assim e apesar de termos de fazer uma festa como as da França, é uma coisa que vemos bastante no Brasil, e assim é mais fácil fazer diálogo.

- Não, porque é chato fazer esse tipo de tema (festa de aniversário). 
Apreciação dos alunos sobre a atividade: preparação da Maquette para a exposição final.

\section{A Maquette Gigante}

Pergunta: Você gostou da atividade? Sim ou não? Por que?

- Sim, porque foi legal.

- Sim, porque é legal fazer atividades diferentes.

- Sim, pois é uma atividade que junta duas matérias e nós nos divertimos e aprendemos francês e artes ao mesmo tempo.

- Até gostei, mas achei muito corrida e as provas foram ao mesmo tempo, mas se tivesse mais tempo seria mais legal.

- Sim, porque foge da rotina de aulas dadas em classe e lições.

- Sim, mas eu acho que poderíamos ter feito com mais capricho e com um material melhor, não só com papelão e tinta.

- Não, é muito chato

- Não, por causa do tempo.

- Não pela falta de tempo para a apresentação

- Sim me ajudou muito a definir o que quero para o futuro.

- Sim, porque eu adoro fazer maquette.

- Sim, porque eu adoro trabalhar com isso, Não, porque não deu tempo e se fosse feito de madeira... 


\section{ANEXO II - Questionário: A classe em relação às línguas estrangeiras}

1. Há quanto tempo você estuda Francês? ( ) meses ( ) anos

2. Você fala em casa alguma outra língua além do português? ( ) sim ( ) não Se sim, qual ou quais?

1.1

1.2

3.Você estuda, fora da escola, alguma língua estrangeira? Se sim, qual ou quais?

3.1

3.2

4. Para você, quais as duas línguas mais importantes no mundo atual?

4.1

4.2

5. Quais as duas línguas que você gostaria de falar?

5.1

5.2

6. Nas aulas de Francês, quais as duas atividades de você mais gosta?

6.1

6.2

7. Nas aulas de Francês, quais as duas atividades de que menos gosta?

7.1

7.2 
Tabulação:

\section{Respostas obtidas ao Questionário:}

Questão 1: Há quanto tempo você estuda francês?

Questão 2: Você fala em casa alguma língua além do português?
11 - inglês
07 - francês
04- espanhol
01- japonês

Questão 3: Você estuda, fora da escola, alguma língua estrangeira? Se sim, qual ou quais?

- 16 -inglês

- 11 - nenhuma língua estrangeira

- 02 - francês

- 01 - espanhol

Questão 4: Para você, quais as duas línguas mais importantes no mundo atual?

- 30 - Inglês

- 15 - Francês

- 12 - Espanhol

- 01 - Alemão

Questão 5: Quais as duas línguas que você gostaria de falar?

- 17 - Francês

- 16 - Alemão

- 15- Inglês

- 09 - Ialiano

- 06 - Árabe

- 02 - Chinês

- 01 - Japonês

Questão 6: Nas aulas de Francês, quais as duas atividades de que mais gosta?

- 14 - diálogos (JdR)

- 09 - vídeo

- 08 - trabalhos em grupo 
- 04 - Simulação Global

- 02 - informática

- 02 - relaxamento

- 01 - redação

- 01 - leitura

Questão 7: Nas aulas de Francês, quais as duas atividades de que menos gosta?

- 12 - exercícios de fixação 6 alunos gostam menos de gramática

- 04 - provas

- 01 - "exposé"

- 01 - JDR

- 01 - redação

- 01 - leitura

- 01 - trabalhos em grupo

- 01 - ditado 


\section{Anexo III - Questionário Final}

Nome data 7a. P

\section{Questionário Final}

1- Há quanto tempo você aprende Francês?

2- Você gosta da Lingua Francesa? Sim ou não ? Por quê?

3- Qual a importância de aprender Francês nos dias de hoje?

4-Você acha que o trabalho desenvolvido pelo professor de Francês foi bom? Sim ou não? Por quê?

5- O que seu Professor de Francês poderia ter feito para melhorar?

6- Você acha que aprendeu melhor Francês através da Simulação Global (construção de Boubolet)? Sim ou não? Por quê?

7- Você aprende melhor Francês através do Método Gramática-Tradução? Sim ou não ? Por quê?

8- O que mudou do ano passado para esse ano com relação ao ensino da Língua Francesa?

9- Foi fácil trabalhar em grupo? Sim ou não? Por quê?

10- Hoje, você gosta mais do que antes ( ano passado) da disciplina: Francês? Sim ou não? Por quê?

11- Você deseja falar fluentemente Francês? Sim ou não? Por quê? 
Tabulação:

Respostas dadas ao Questionário Final *

Questionário Final

Questão 1: Há quanto tempo você aprende Francês?

- 02 - 7 anos

- $09-6$ anos

- $04-5$ anos

- 02 - 4 anos

- 04 - 3 anos

- 02 - 1 ano

Questão 2: Você gosta da Língua Francesa? Sim ou não? Por quê?

- $17-\operatorname{sim}$

- 04 - não

- 01 - mais ou menos

Questão 4: Você acha que o trabalho desenvolvido pelo professor de Francês foi bom? Sim ou não?

- $\operatorname{Sim}-23$

- Não - ---

Questão 6: Você acha que aprendeu melhor Francês através da Simulação Global ( construção de Boubolet) Sim ou não? Por quê?

- $18-\operatorname{sim}$

- 04 - não

- 01 - mais ou menos

Questão 7: Você aprende melhor Francês através do Método GramáticaTradução? Sim ou não? Por quê?

- $10-\operatorname{sim}$

- 12 -não

- 01 abstenção 
Questão 9: Foi fácil trabalhar em grupo? Sim ou não? Por quê?

- $12-\operatorname{sim}$

- 08 - não

- 03 - mais ou menos

Questão 10: Hoje, você gosta mais do que antes (ano passado) da disciplina: Francês? Sim ou não? Por quê?

- $16-\operatorname{sim}$

- 04 - não

- 03 - na dúvida

Questão 11: Você deseja falar fluentemente Francês? Sim ou não? Por quê?

- $21-\operatorname{sim}$

- 00 - não

- 01 - tanto faz 
ANEXO IV - Tableau des contenus - Café Crème 2

\section{T a b I e a u d e s c o n t e nus}

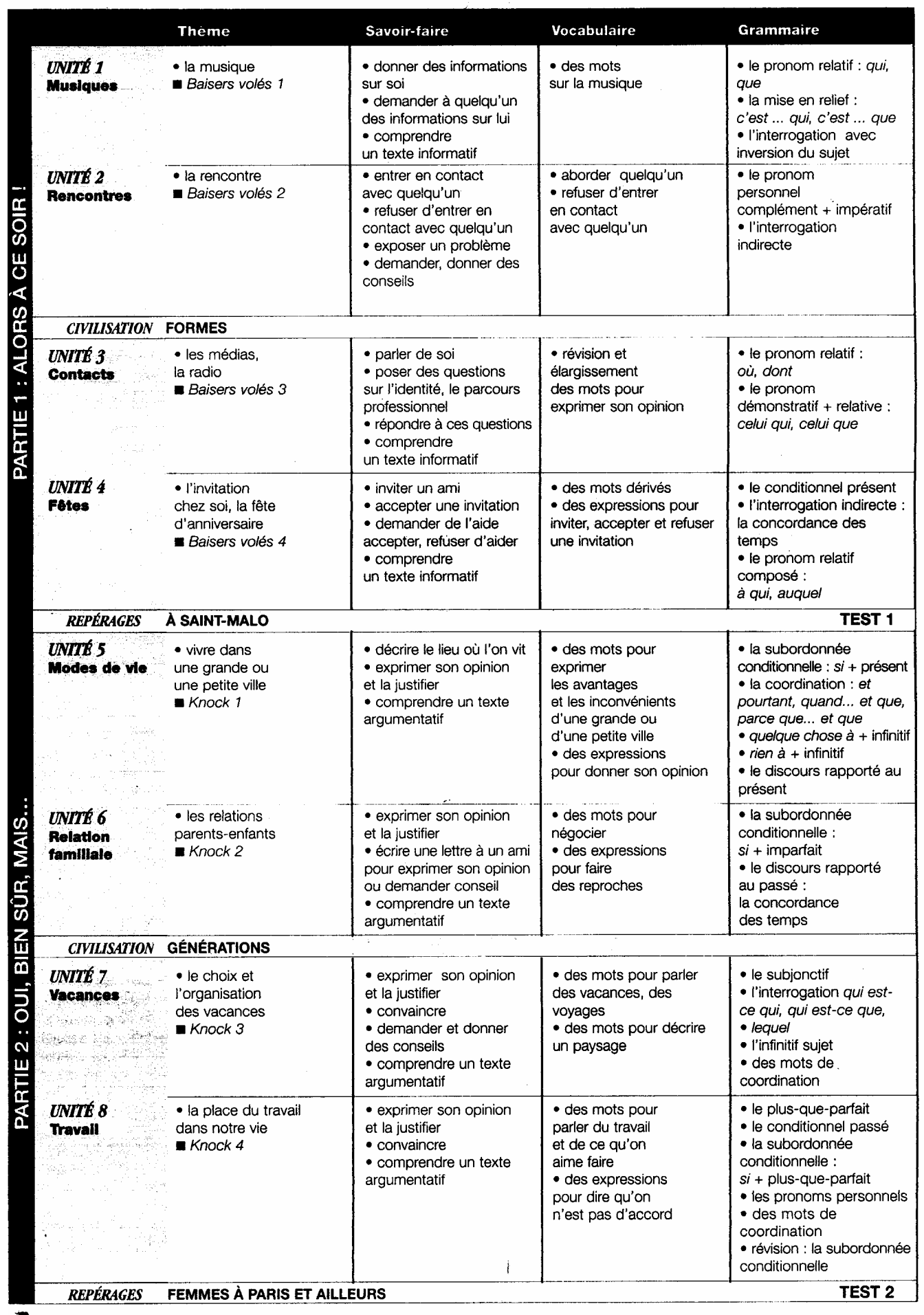


ANEXO V - Perfil dos habitantes de Boubolet Fichas dos Habitantes de Boubolet.

\author{
Nom: Rainer \\ Prénom: Anne \\ Age: 35 ans \\ Profession: maire
}

Caracteristiques Physiques: brune, petite, cheveux ondulés, yeux marrons

Personnalité: timide, mais froide

D'autres: 2 fils, divorcée 2 fois

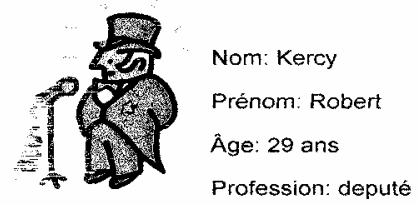

Caracteristiques Physiques: gros, de taille moyenne

Personnalité: sérieux

D'autres: marié, avec 3 enfants

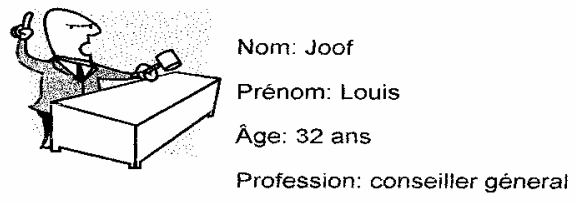

Caracteristiques Physiques: chauve, grand, yeux verts

Personnalité: énergique

D'autres: célibataire

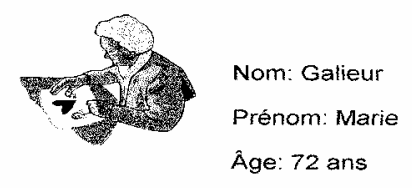

Profession: retraitée

Caracteristiques Physiques: petite, maigre, cheveux blancs

Personnalité: douce et curieuse

D'autres: mariée, avec 3 fils et 2 petits-fils

\title{
Boubolet
}

\author{
Nom: Da Silva \\ Prénom: Gilbreto \\ Âge: 37 \\ Profession: maçon \\ Caracteristiques physiques: maigre, grand et fort. \\ Personalité: sympathique et contante. \\ Dautres: il a deux enfants. \\ Nom: Lima \\ Prénom: Francois \\ Âge: 51 \\ Profession :peintre \\ Caracteristiques physiques :petit et gros. \\ Personalité: realiste. \\ D'autres: Il aime la musique. \\ Nom: D'Abreu. \\ Prénom: Furlan \\ Âge: 25 \\ Profession: garagiste. \\ Caracteristiques physiques : grand et fort. \\ Pexsonalité : nerveux \\ D'autres: It est marie

Nom: Darbon

BOUBOLET

Prénom: Antoine

Âge: 23

Profession: DJ

Caractheristiques Phisiques: brun, yeux noirs, maigre.

Personalité: moderne, attentieux.

D'autres: il veut être fameux.

Nom: François.

Prénom: Jean.

Âge: 16.

Profession: lycéen.

Caractheristiques Phisiques: grand, maigre, cheveux blond, yeux verts.

Personalité: amusent, sympatique, um peu distrait

D'autres: il veut être une personne avec succès.

Nom: Pivot.

Prénom: Diane

Âge: 15

Profession: lycéenne.

Caractheristiques Phisiques: cheveux orange, curt, yeux bleus. Personalité: elle veut changer le monde selon sa pensée.

D'autres:

Nom: Binoche.

Prénom: Anne

Age: 35 .

Profession: avocate.

Caractheristiques Phisiques: yeux bleus, cheveux noir, grande.

Personalité:sentimentale, beaucoup ocupée.

D'autres: elle veut avoir plus de temps pour ses enfants. 


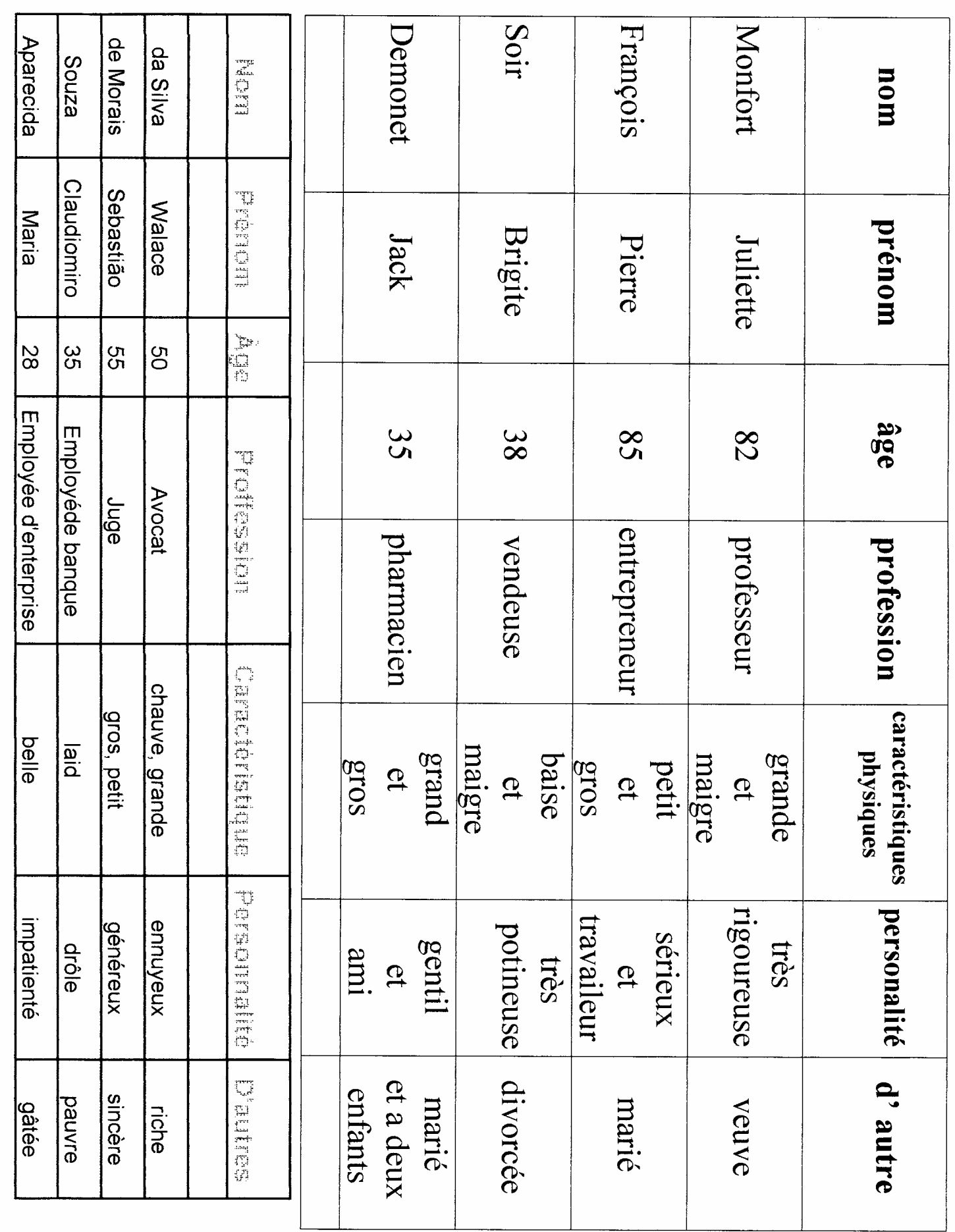

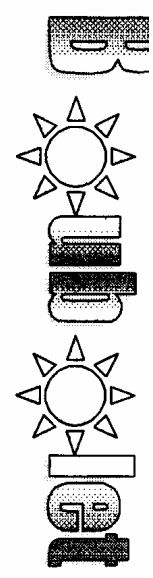


ANEXO VI - Textos Sobre Boubolet Fôlders, Cartazes, Menus e Revistas Culturais.

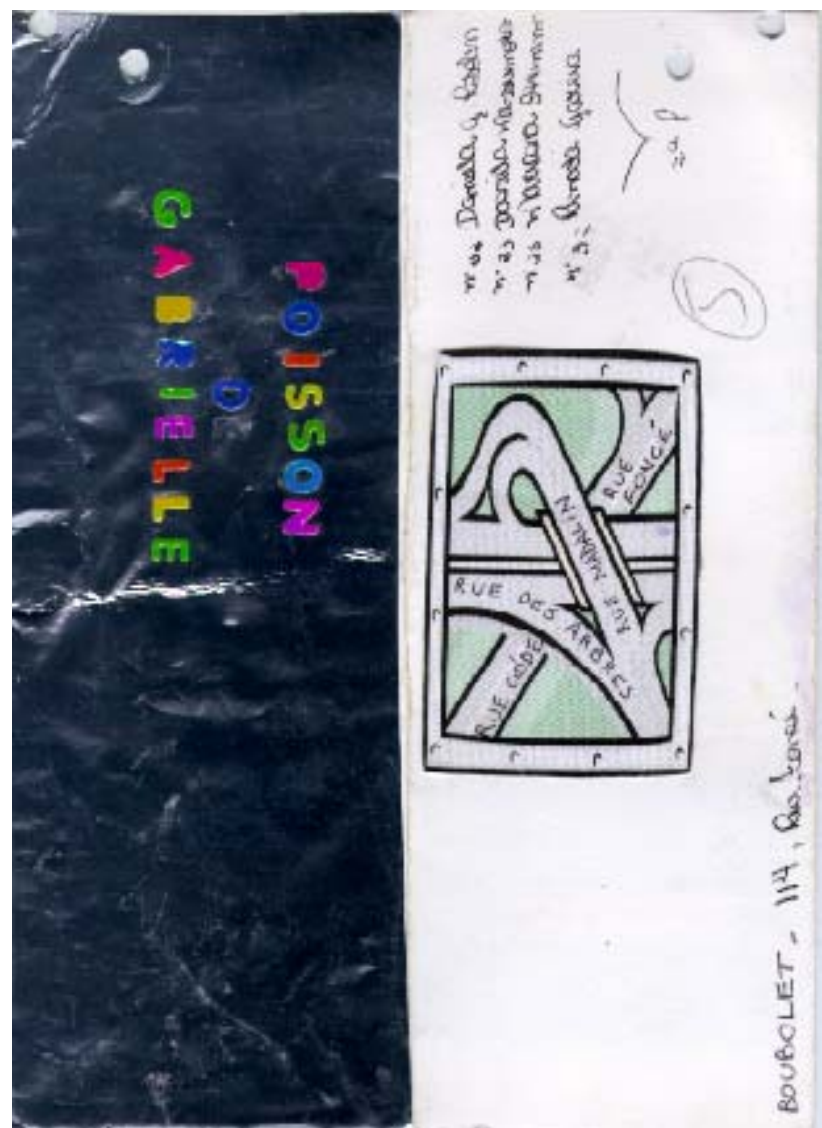

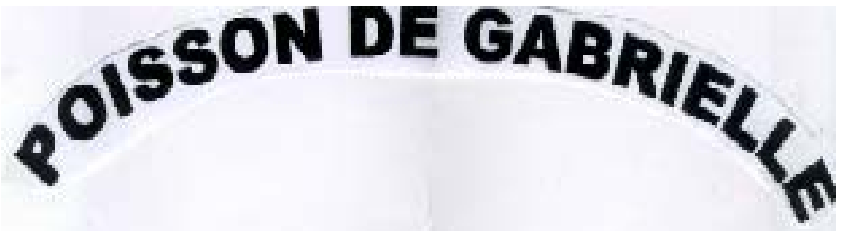

Venez á Bouhóet et mangez le meilleur poisson de la région

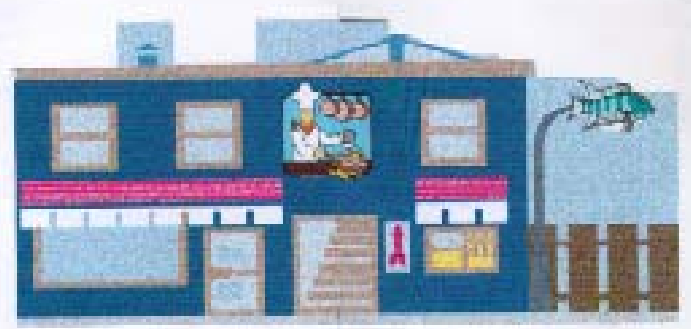

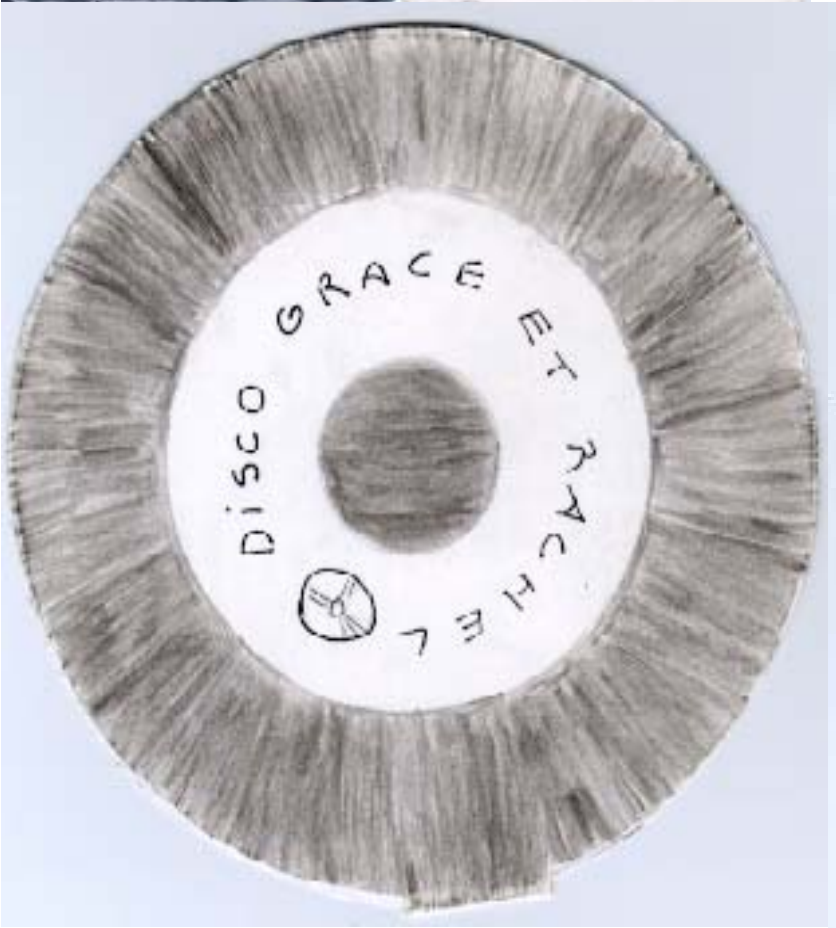

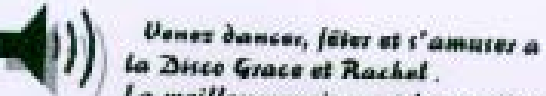
Lo meillour mastigues at les meilleuss Dis de Beubelet tout ici. Uens pouves feter volie anniventaire avec neks, Tulofonez all numernet 3035,9095 et padioz suves Grace ou Rachel.

\section{MISCO GRACC EL RACHCL.}

Adresre: Baulavand Gambeds $A$ Bombelot. De. Mardi a Dimanche, cutre 6630 ot mintait. 


\section{Magazine culturel de France}

\section{N 1 - Novembre 2001}

Editeurs: Marcet, Victor, Enc, Brum et Thascia

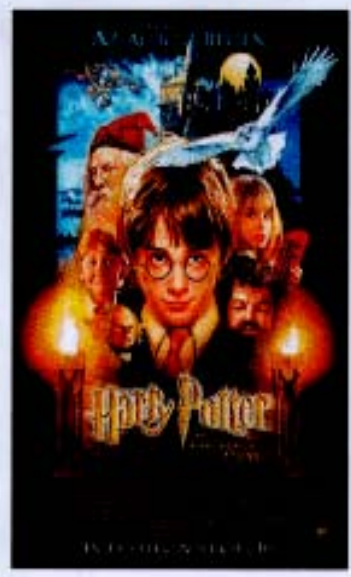

Harry Potter Le film
Le film Harry Potter a fait sauter les bureaux de billets, moins en fonction du petit sorcier que par stratégie marketing.

Pendant son premier jour de représentation à Washington, le chiffre d'affaires du film de Chris Columbus, "Harry Potter et la Pierre Philosophale", a ramassé le total de USD $\$ 31,3$ (trente et un millions e trois cents mil dollars).

Selon ce démarrage de vendredi dernier, en arrivant aux salles de cinéma des États Unis le film pourra battre le record des premières et dépasser "La Ménace Phantôme", l'épisode initial de la série Guerre Dans Les Étoiles de George Lucas.

Cependant, le succès semble parvenir moins grâce aux pouvoirs magiques du jeune protagoniste que à la séduction annoncée par le directeur et à l'exécution de la divulgation de la campagne marketing.

En outre, le désir des Américains du nord a augmenté par les arrêts de congé, en fonction de la crainte du terrorisme essayé contre eux dès le 11 septembre.

Le film dirigé par Chris Columbus, basé sur le best-seller de J. K. Rowling, a été préparé pour monopoliser le public pendant un certain temps.

La "Ménace Phantôme" a rassamblé USD\$ 28,5 millions (vingt huit millions de dollars e demi).

Le nouveau pas de page de l'Homme Araignée arrive au Net.

Attention admirateurs de l'Homme Araignée: un nouveau pas de page avec des images du film du super-héros deviendra disponible aujourd'hui au Net.

Le vidéo-clip avec des scènes de la production de Sam Raimi va pouvoir être vu par les utilisateurs enrégistrés du site officiel de la bande, www.sony.com/SpiderMan/network.

Le vidéo présente des nouvelles images de Peter Parker (Tobey Maguire) comme l'Homme Araignée et le survol de l'Elfe Vert (Willem Dafoe) sur les nues de New York.

L'Homme Araignée débutera aux États-Unis au mois de mai 2002.

Pendant les semaines prochaines, le studio Sony décrira la nouvelle conception des promesses pour la page officielle du film. 
ANEXO VII - Jornal: Boubolet Express

\section{Faits-Divers.}

\section{Boubolet Express}

Le premier assassin à Boubolet

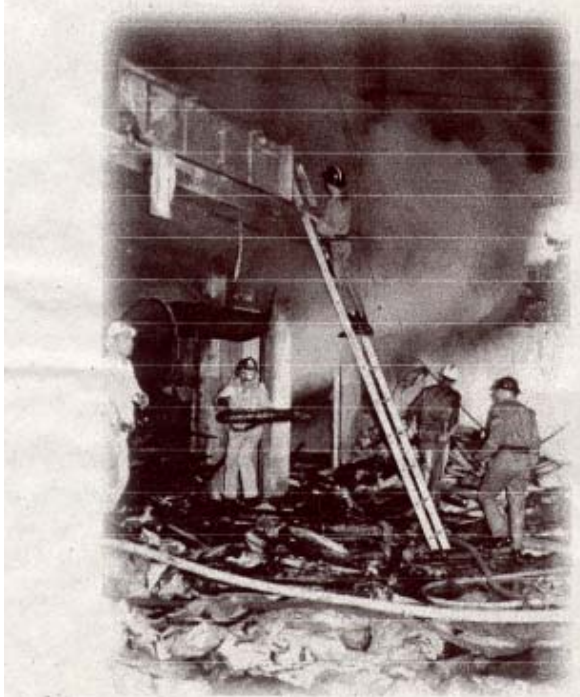

Le premier assassin à Boubolet :Hier, le propriétaire du restaurant Poisson de Marcelise a été assassiné par une bombe qui a explosé dans le restaurant.

\section{BOUBOL [E⿱ EXPRESS Vendredi, le 17 août 2001 - N 1 - An I}

CARNAGE: 15 PERSONNES ASSASSINÉES À LA PLAGE DE BOUBOLET SEULEMENT $1 \mathrm{~A}$ SURVÉCU

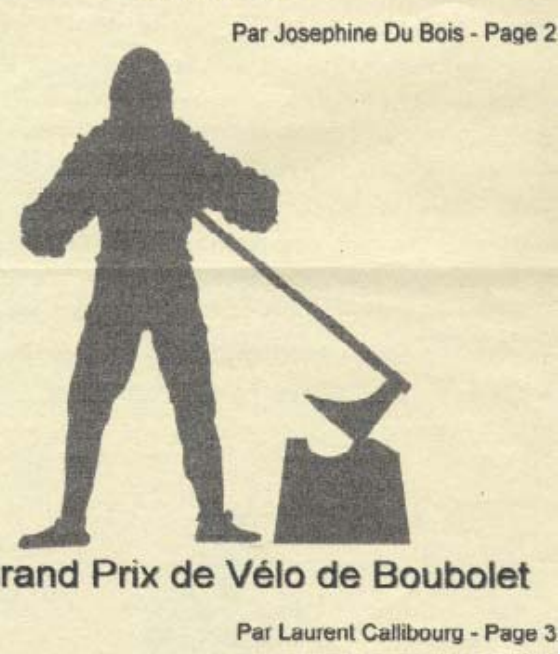

Fossiles de dinosauriens trouvés à

Par Richard Bonnet - Page 4

1er Grand Prix de Vélo de Boubolet

$$
\text { Boubolet }
$$

\section{Express de Boubolet}

Dimanche,12 février, 2001.

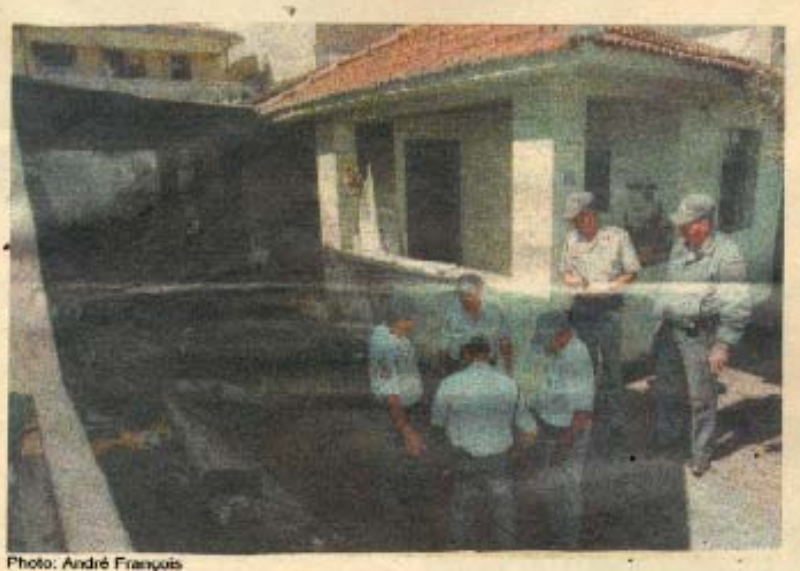

Aprés une féte à la plâge de Boubolet deux jeunes alcoolisés conduisent en etat d'ivresse. Le passager est mort dans I'accident.

\section{BOUBOLET EXPRESS}

MARDI

BOUBOLET, LE 21 AOUTT 2001

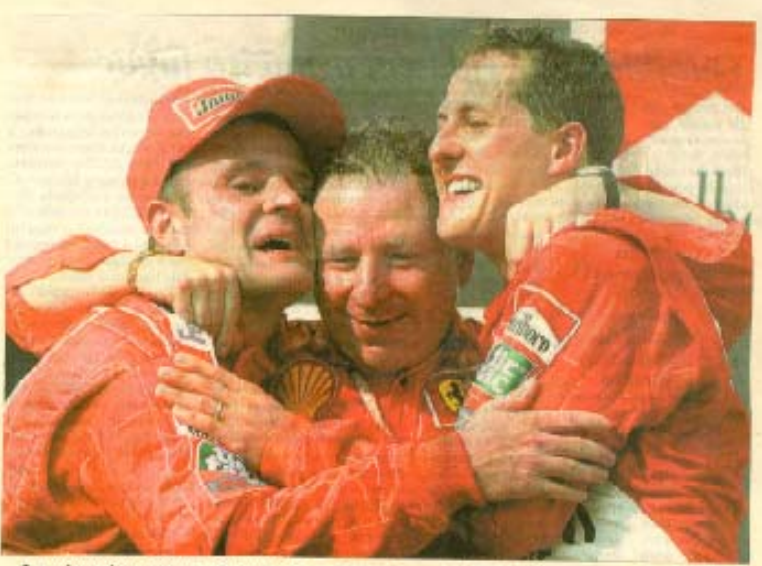

La réceptivu ruuge - Schumacher commémore le titre du Ferrari avec Rarichcllo at le directeir lean Tonlt 


\section{Quince individus ont éte violemment assassinés la nuit passde}

\section{a h playe de Bouboles}

Par Josepltine Dubois

L'assassin est apparemment racisto, parce que jusqu'ici it a tué exclusivement des pensonines de race noire, laissant enforicéte une hadie sur chacune.

Les meurtes ont euivi l'ordre alphabetique des nome. Lee familles des vicumes ont récu leurs os et leurs yeux, accompagnes d'un billet menaçant: "Vous pouvez devenir le prochain 1!!"

Lassossin resto inconnu of los rocherches se poursuivent. Les policiers s'efforcent de vouver qui serait tel assassin, cherchant des traces de ADN ou des empreites digitales sur les haches, mais juaqu'è prósent ils ont échoué, pulsque apparemment rassassin pontait des gants.

Une des victimes, qui serait la seizieme, a réussit fuir, à communiquer avec la police et la presse, et nous a donné son témoignage: "Je n'ai pas vu le visage de rassassin, a cause de l'obscunte ef parce qu'il etait masqué. te n'ai pas mémo notó ces youx. II était haut, gros et sa voik était aigue."

La police de Boubolet patrouille sans cesse la plage et la ville toute entiere, mais altention, cet homme reste tres dangereuxl

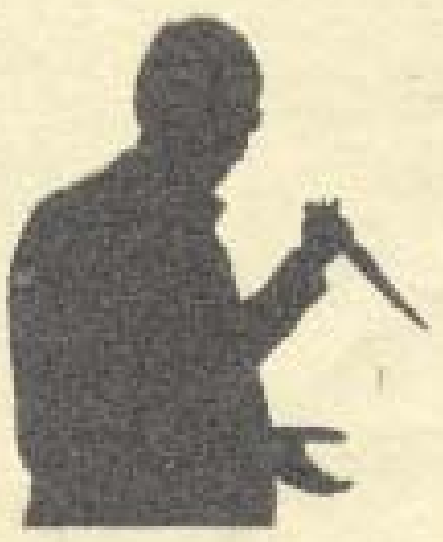




\section{ANEXO VIII - Textos referentes à atividade: Festival de música \\ O festival de Musica de Boubolet \\ Exemplo 1}

Tous les ans, pendant la fête de Pâques, le grand festival de Boubolet réunit la France. Ses artistes chantent tous les types de musique, par exemple opéra, jazz, rock, rap.... Beaucoup de touriste viennent regarder sés artistes et écouter la musique.

Pour avoir des informations, contactez lês organisateurs du festival.

Téléphone: 2961-8378

650, rue du Louvre

\section{Exemplo 2}

Le festival Bouboletiene il y a lieu de quatre em quatre ans em Boubolet, France. Dans cette Festival il y a tous samplement jazz et blues. Les chanteurs viennent du monmde entier et pour entre vous devez payer 60 francs pour le ticket de quelques jouer. Cette festival aura lieu du 08 au 19 avril. Le public vient de tous le monde pour écouter les meilleurs chanters de jazz et blues de tous le monde. Pour more information telephone au 0236393956. 
ANEXO IX - Mapa da Cidade

Mapa da Cidade.

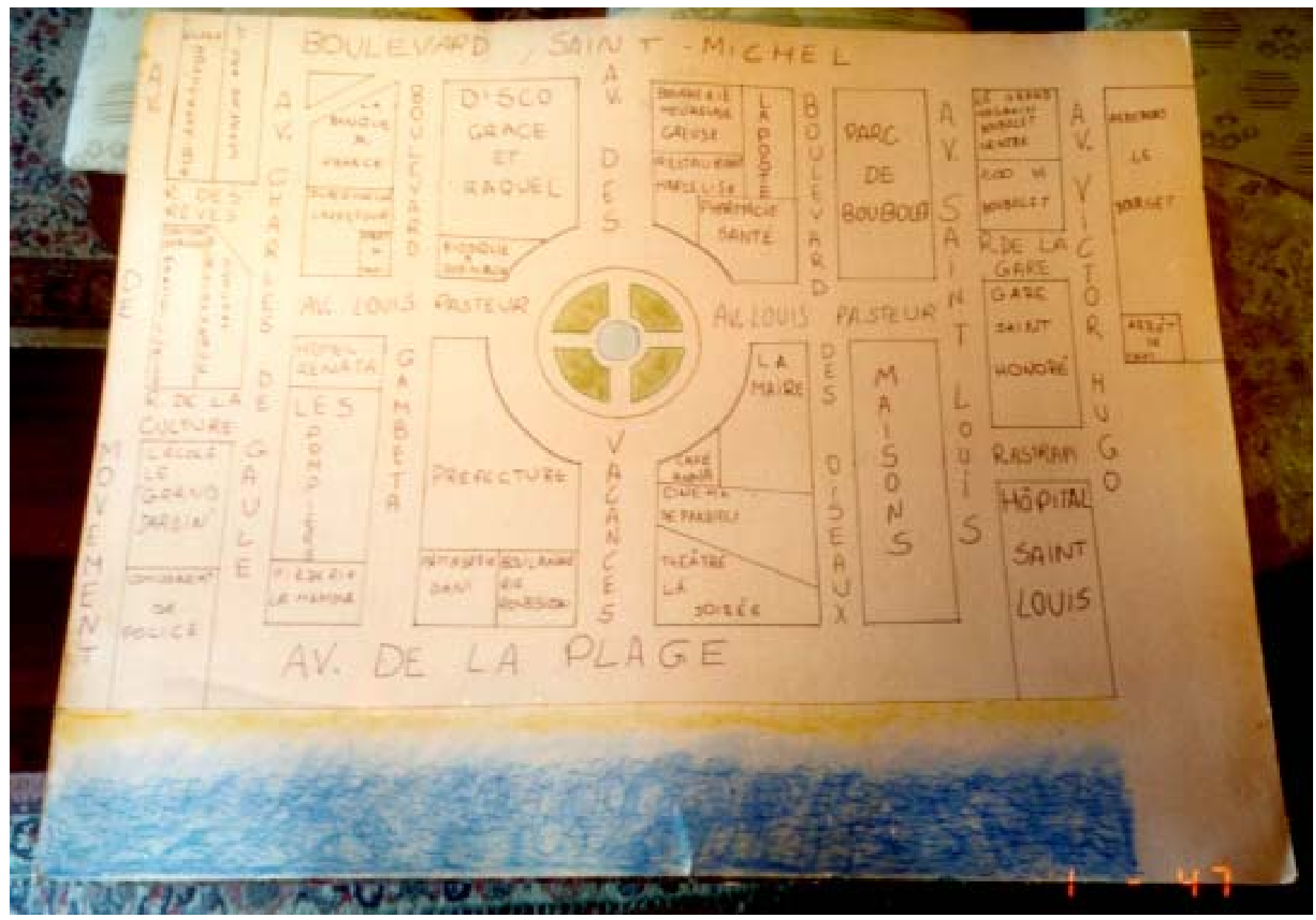




\section{ANEXO X - Convites para a exposição final}

\section{Convites}

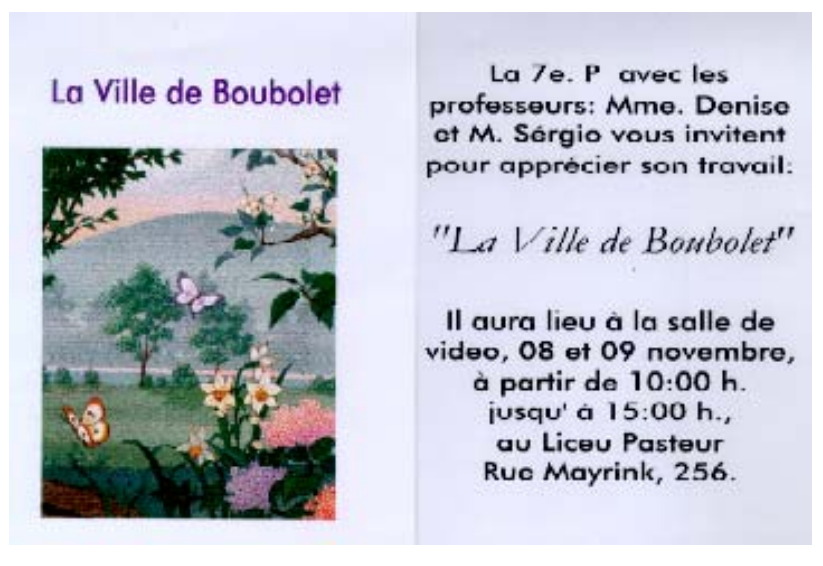

\section{Invitation}

Les habitants de Boubolet ont le plaisir d'inviter toutes les personnes qui s'interessent a $I^{\prime}$ architeture française, pour faire une charmante promenade dans notre maquete géante de la ville.

I' 'expose est magnifique ot fait avec du matériel recyclé pour les eleves de la $7^{\circ} \mathrm{P}$.

Ello aure lisu à la fondation Iycée Pasteux, du 12 au 13 novembre

Les eleves de la $7^{\prime} p$

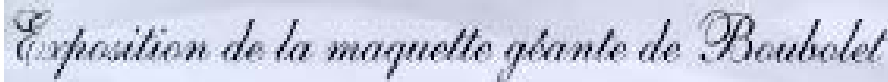

Chers paranis, ands of familhers,

Hy aura une exposition de la maquette de Boubvel cosshinile

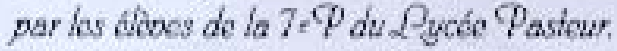

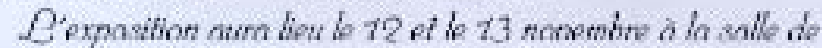
oidíto.

\section{Votre presence est Ints imporiante. Obliges. eteres de la 7P.}

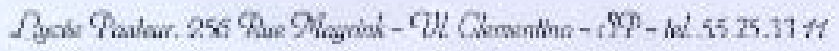

Nous, éleves de $7 \quad \mathbb{P}$, vous vous invitons pour Cexposition de notre grande maquette d une village qui s'appelle Boubolet.

Cela aura fieu fe 9 Novembre, au Lycée Pasteur.

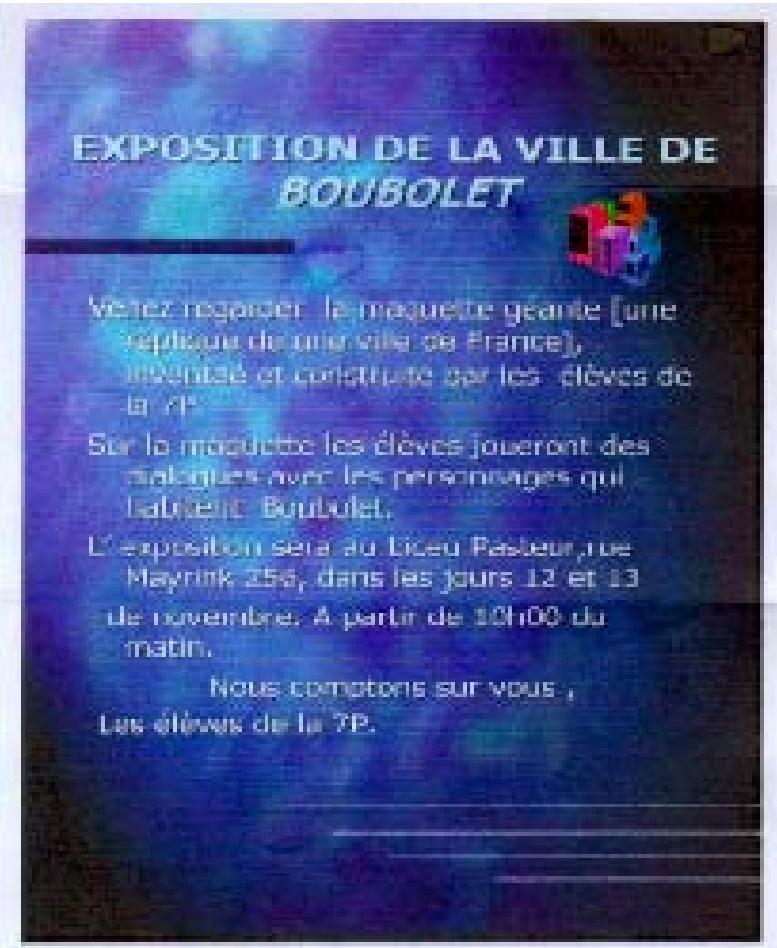




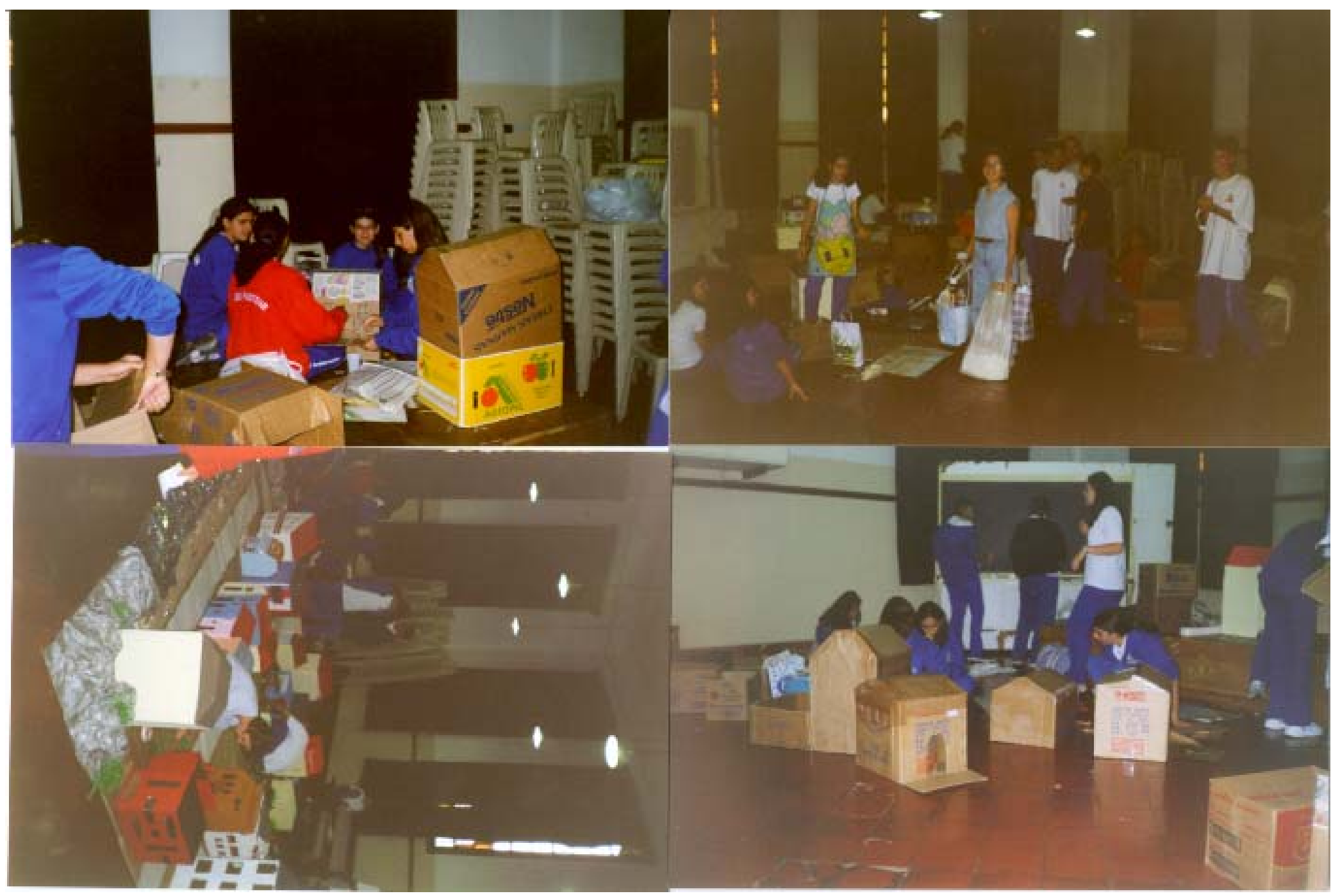

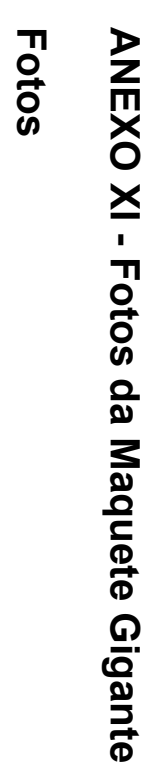




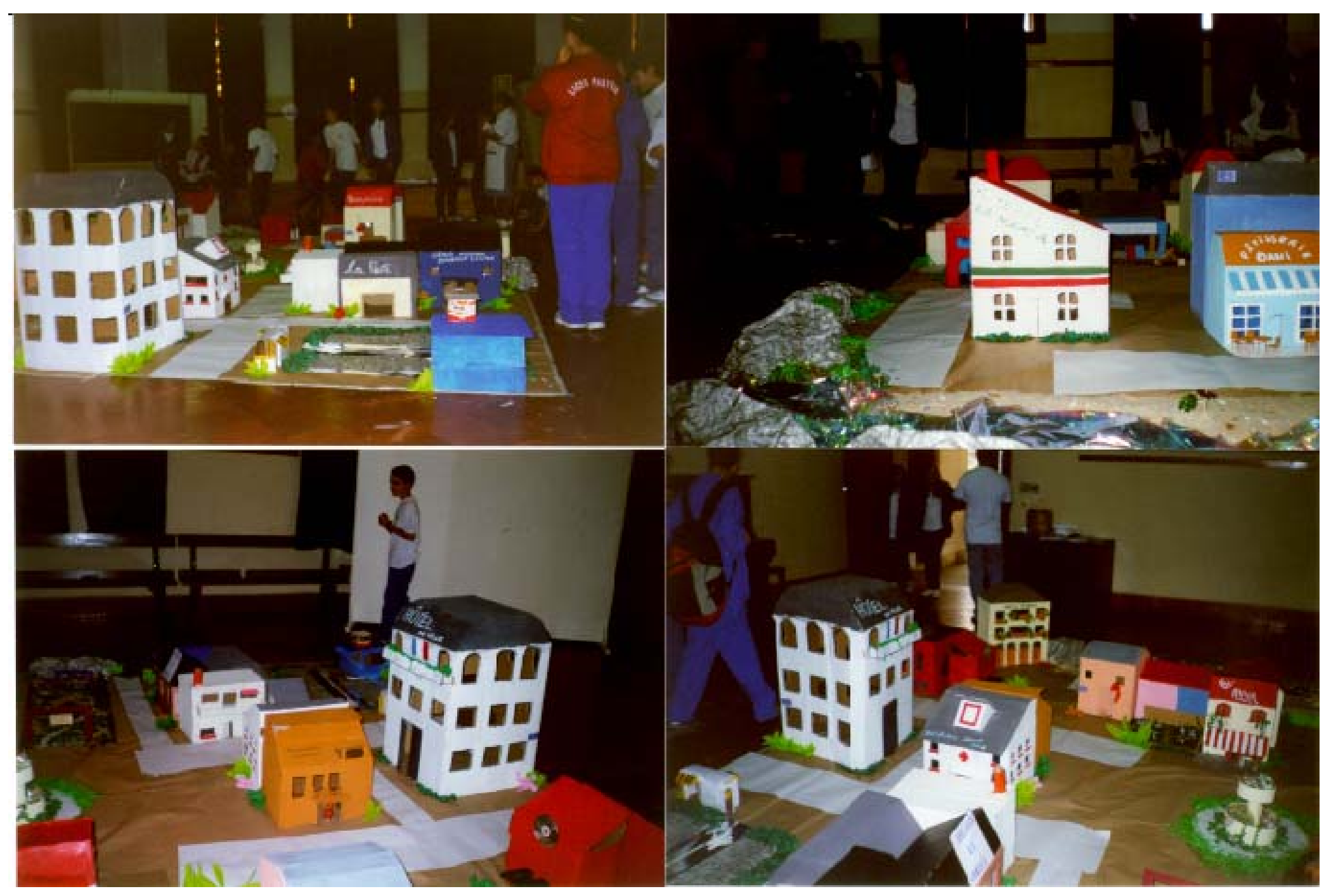

